\title{
FOTOGRAFÍA, ESCUELA Y PROPAGANDA DURANTE LA GUERRA CIVIL: UNA APROXIMACIÓN DESDE NOVA IBERIA*
}

\author{
Photography, school and propaganda during the Spanish Civil \\ War: an approach from Nova Iberia
}

\section{Avelina Miquel Lara ${ }^{\beta}$ y Francisca Comas Rubí ${ }^{\alpha}$}

Fecha de recepción: 06/06/2017 • Fecha de aceptación: 21/11/2017

Resumen. La guerra civil española fue ampliamente cubierta tanto por reporteros nacionales como internacionales. Miles de imágenes del conflicto, en el frente o en la retaguardia, fueron difundidas con fines propagandísticos dentro y fuera de nuestras fronteras. Entre las temáticas retratadas, las relacionadas con la educación en general y la escuela en particular ocuparon un lugar importante, sobre todo en el bando republicano.

El objetivo de este artículo es conocer el uso que se hizo de esta imagen escolar como propaganda durante el conflicto en el bando republicano. Para ello nos centramos en la tarea realizada por el Comissariat de Propaganda de la Generalitat de Cataluña, un organismo creado a inicios de la guerra para la difusión de información y, en concreto, en el análisis de Nova Iberia, revista ilustrada emblemática de este organismo, en la que colaboraron reputados fotógrafos y que tuvo una importante difusión internacional.

A partir del análisis de los reportajes gráficos de esta revista intentaremos interpretar el discurso que se construye a través de la imagen escolar, su

\footnotetext{
* Este artículo se ha realizado en el marco del proyecto «La fotografía publicada como representación de los cambios y las continuidades en la cultura escolar (1900-1970)», EDU2014-52498-C2-2-P, financiado en el Programa Estatal de Fomento de la Investigación Científica y Técnica de Excelencia, Subprograma Estatal de Generación de Conocimiento, en el marco del Plan Estatal de Investigación Científica y Técnica y de Innovación 2013-2016. Ministerio de Economía, Industria y Competitividad (AEI/FEDER, UE).

${ }^{\beta}$ Grup d'Estudis d'Història de l'Educació (IRIE). ). Departament de Pedagogia i didàctiques especifiques. Facultat d'Educació. Universitat de les Illes Balears. Ctra. Valldemossa, Km. 7,5. 07122 Palma de Mallorca. España. avelina.miquel@uib.es

${ }^{a}$ Grup d'Estudis d'Història de l'Educació (IRIE). Departament de Pedagogia i didàctiques especifiques. Facultat d'Educació. Universitat de les Illes Balears. Ctra. Valldemossa, Km. 7,5. 07122 Palma de Mallorca. España. xisca.comas@uib.es
}

Cómo citar este artículo: Miquel Lara, Avelina y Francisca Comas Rubí. «Fotografía, escuela y propaganda durante la Guerra Civil: una aproximación desde Nova Iberia». Historia y Memoria de la Educación 8 (2018): 231-269. 
intención propagandística y su significado en el marco de un conflicto bélico concebido por muchos no sólo como una guerra civil sino como una auténtica revolución social.

Palabras clave: Fotografía; Escuela; Guerra Civil; Prensa ilustrada; Comissariat de Propaganda; Cataluña

Abstract. The Spanish civil war was widely covered by both national and international reporters. Thousands of images of the conflict, on the front or behind the lines, were broadcast for propaganda purposes inside and outside our borders. Among the themes portrayed, those related to education in general and the school in particular occupied an important place, especially on the Republican side.

The objective of this article is to examine the way this image of the school was used as propaganda by the Republican side during the conflict. We focus on the task carried out by the Catalan Government's Commissariat de Propaganda, an organization created at the beginning of the war in order to spread the information. We specifically focus on the analysis of Nova Iberia, its most emblematic illustrated magazine; in addition to the collaboration of renowned photographers, this publication, this enjoyed considerable international circulation.

Based on the analysis of the graphic reports of this magazine, we will try to interpret the discourse that is constructed through the school image, its propagandistic intention and its meaning in the context of a war conceived by many not only as a civil war but as an authentic social revolution.

Keywords: Photography; School; Spanish Civil War; Illustrated magazines; Comissariat de Propaganda; Catalonia

\section{INTRODUCCIÓN}

Al inicio de la Guerra en julio de 1936, y con España dividida entre el bando republicano y el sublevado, se puso claramente de manifiesto la superioridad del gobierno republicano en cuanto a infraestructuras de comunicación (prensa, cartelismo, editoriales, cine, radio, etc.), de las que se hizo uso no sólo para la difusión interna y externa de información, sino también para la propaganda tanto en la retaguardia como en el extranjero. Entre estos medios propagandísticos, la fotografía, por su fuerza visual, adquirió una gran relevancia. ${ }^{1}$

\footnotetext{
${ }^{1}$ La propaganda puede tener intencionalidad informativa o persuasiva, pero como acto de comunicación, por muy neutral que intente ser, siempre influye en el receptor. Tras la I Guerra Mundial
} 
Fotógrafos españoles y extranjeros de todo tipo, como reporteros gráficos, retratistas, o fotógrafos ambulantes dieron cobertura al conflicto bélico. El resultado fue que la Guerra Civil Española (1936-1939), como consecuencia de su cobertura mediática, generó una interesante cantidad de imágenes fotográficas que se divulgaron dentro y fuera de nuestras fronteras. ${ }^{2}$

Además de otros medios de comunicación en auge, como la radio o el cine, ${ }^{3}$ la prensa en general, y la ilustrada en particular, contaba ya con una importante tradición. Madrid, Barcelona y Bilbao eran las tres ciudades desde donde mayoritariamente se articulaba este sistema comunicativo propio ya de una sociedad de masas.

se produjo una reflexión sobre este fenómeno y se asentaron las primeras bases de la teoría de la propaganda. En los años treinta el estudio de la propaganda en la guerra y su influencia social estaba en auge. La propaganda del Comissariat se podría encuadrar mayoritariamente en la vertiente informativa de esta disciplina, pero no por ello deja de tener una intencionalidad persuasiva. Ningún gobierno democrático usaría la palabra propaganda en el nombre de una institución si conllevase una connotación negativa. Para saber más sin ánimo de ser exhaustivos, recomendamos: Harold D. Lasswell, Porpaganda Techinique in the World War (Nueva York: Knopf, 1927); Jacques Ellul, Historie de la propagande (París: P.U.F., 1967); Alejandro Pizarroso Quintero, Historia de la propaganda: notas para un estudio de la propaganda política y de guerra (España: EUDEMA Universidad, 1990); Jesús Timoteo Álvarez, Historia y modelos de la comunicación en el siglo XX. El nuevo orden informativo (Barcelona: Ariel 1987) y Del viejo orden informativo, Introducción de la Historia de la Comunicación, la Información y la Propaganda de Occidente, desde sus orígenes hasta 1880 (Madrid: Actas, 1991), o Jesús Timoteo Álvarez et al., Historia de los medios de comunicación en España. Periodismo, imagen y publicidad (1900-1990) (Barcelona: Ariel, 1989).

${ }^{2}$ Para saber más sobre fotografía, fotografía de guerra y fotoperiodismo, consultar: Publio López Mondejar, Historia de la fotografía en España. Fotografía y sociedad, desde sus orígenes hasta el siglo XXI (Barcelona: Lunwerg, 2005); Marie-Loup Sougez (coord.), Historia general de la fotografía (Madrid: Cátedra, 2006); Beaumont Newhall, Historia de la fotografía (Barcelona: Editorial Gustavo Gili, 2001); Carlos Abreu Sojo, Los géneros periodísticos fotográficos (Barcelona: Ediciones Cims, 1997); Antonio Jesús González, Fotógrafo de guerra: la fotografía de guerra en España, 1859-1939 (Córdoba: Diputación de Córdoba, 2015); Manuel Alonso Erausquin, Fotoperiodismo. Formas y códigos (Madrid: Editorial Síntesis, 1995); Jorge Pedro Sousa, Historia crítica del fotoperiodismo occidental (Sevilla: Comunicación Social ediciones y Publicaciones, 2003), y Juan Miguel Sánchez Vigil y María Olivera Zaldua, Fotoperiodismo y República (Madrid: Cátedra, 2014).

${ }^{3}$ Para conocer más sobre los documentales educativos, recomendamos la lectura de los siguientes trabajos: Josep Casanovas i Prat y Eulàlia Collelldemont Pujadas, «La fachada de la escuela. La imagen de la enseñanza en los films documentales de inauguración de grupos escolares durante la dictadura de Primo de Rivera», en Espacios y patrimonio histórico-educativo, coords. Paulí Dávila Balsera y Luis María Naya Garmendia (Donostia: Erein, 2016), 663-678, y Eulàlia Collelldemont Pujadas y Josep Casanovas i Prat, «Los documentales y noticiarios como texto de apertura para pensar la educación estético-política», Historia y memoria de la Educación 5 (2017): 469-487. 
En Cataluña la prensa gráfica se había iniciado a finales del siglo XIX, adquiriendo cada vez más protagonismo durante el primer tercio del siglo xx. En 1936 Barcelona contaba con una importante industria periodística que se traducía en decenas de diarios y revistas que aumentaron más su número al inicio de la contienda. Con la guerra, a pesar de que en un principio se considerase poco democrático, también se inició un proceso de control de la información textual y gráfica, que implicó el filtrado y supervisión de la difusión a través de organismos que se crearían con este fin. En noviembre de 1936 el gabinete de Largo Caballero creó el Ministerio de Propaganda; un mes antes, sin embargo, la Generalitat de Cataluña ya había creado su propio organismo para la difusión de información, el llamado Comissariat de Propaganda. ${ }^{4}$

La labor del Comissariat durante los primeros años de guerra fue muy activa. El objetivo de este organismo se dirigía tanto al frente y retaguardia, como al exterior. Se trataba de animar y motivar a quienes luchaban en el frente, de dar esperanza a quienes trabajaban en la retaguardia y de crear opinión favorable, traducida en ayuda de todo tipo fuera de las fronteras de España. Para ello se dispuso de todos los medios de comunicación posibles en Cataluña, así como de las técnicas y tendencias más modernas.

Entre los medios usados estuvieron las revistas, alguna de la cuales, en un claro intento de causar más impacto sobre la opinión pública, priorizaron las imágenes al texto. Las fotografías se usaron con fines más propagandísticos que documentales, llegando incluso a utilizar la misma fotografía en distintos contextos y con pies de foto totalmente diferentes, o fotografías anteriores al inicio del conflicto para visibilizar sentimientos con los que la población pudiera sentirse identificada en ese momento, o que pudieran generar sentimientos de empatía o compasión hacia la causa republicana. ${ }^{5}$

\footnotetext{
${ }^{4}$ La obra más completa hasta ahora sobre el Comissariat de Propaganda de la Generalitat de Cataluña es la de Rafael Pascuet y Enric Pujol (dirs.), publicada como La revolució del bon gust, Jaume Miravitlles i el Comissariat de propaganda (Barcelona: Ajuntament de Figueres, Viena Edicions, 2006).

${ }^{5}$ Es el caso, por ejemplo, de la fotografía de David Seymour «Chim» en la que se ve a una campesina de Extremadura escuchando un discurso político. La imagen es de marzo de 1936, publicada en un reportaje de la revista Regards (14 de abril de 1936), pero se usó en diversas ocasiones durante el conflicto (en prensa y carteles) como si fuese una instantánea tomada durante la guerra, aprovechando la fuerza dramática de la imagen.
} 
Entre las revistas ilustradas que publicó el Comissariat, en este artículo nos centraremos en una en particular, Nova Iberia, por dos motivos. Por una parte, porque se trata de una de las revistas ilustradas de carácter propagandístico de más calidad técnica y belleza plástica, en la que se prioriza la imagen por encima del texto. Y por otra, por el uso propagandístico que hace la revista de la imagen escolar como medio para legitimar su particular lucha contra el fascismo y ganar apoyos dentro y fuera de Cataluña.

\section{EL COMISSARIAT DE PROPAGANDA DE LA GENERALITAT DE CATALUNYA. CREACIÓN, ORGANIZACIÓN, FUNCIONES Y OBRA.}

El Decreto fundacional del Comissariat de Propaganda fue publicado en el Diari Oficial de la Generalitat de Catalunya el 5 de Octubre de 1936. ${ }^{6}$ Este organismo dependió directamente de Presidencia, aunque en septiembre de 1937, dada la envergadura de sus múltiples acciones, pasó a ocupar una Dirección General. Tuvo como objetivo mantener la moral alta tanto en el frente como en la retaguardia, ganar partidarios internacionales dispuestos a romper la política de no intervención de las democracias europeas y apoyar a la República en su lucha contra el fascismo, al tiempo que daba a conocer las singularidades del pueblo catalán. Para

\footnotetext{
${ }^{6}$ Sobre el Comissariat de Propaganda de la Generalitat de Cataluña se han publicado algunos estudios, posiblemente el más completo es la obra homenaje con motivo del centenario del nacimiento de Jaume Mitavitlles: Pascuet y Pujol (dirs.), La revolució del bon gust; también es aconsejable la consulta de Josep Solé i Sabaté y Joan Villarroya i Font, Guerra i propaganda: fotografies del Comissariat de Propaganda de la Generalitat de Catalunya (1936-1939) (Barcelona: ANC-Viena Edicions, 2006); Maria Campillo, Escriptors catalans i compromís antifeixista (1936-1939) (Barcelona: Curial Edicions Catalanes, 1994); la más reciente investigación en forma de tesis doctoral es la de Ramon Batalla i Galimany, «Jaume Miravitlles i Navarra. Intel-lectual, revolucionari i home de govern. Els anys joves, 1906-1939» (Tesis doctoral, Universidad Autónoma de Barcelona, 2010); Josep M. Figueres i Artigues, «El Comissariat de Propaganda de la Generalitat de Catalunya: instrument propagandístic i d'agitació a la reraguarda i instrument de projecció a l'exterior» en La comunicació audiovisual en la història (V Encontre d'Historiadors de la Comunicació), coords. Arnau Company Mates, Jordi Pons Bosch y Sebastià Serra Busquets (Palma de Mallorca: Universitat de les Illes Balears, 2003), 631-654; Pere Puig, «La revolució del bon gust. La guerra que es va guanyar», Presencia 1826, (2007): 2-11; así como biografías sobre personajes que participaron en el Comissariat tales como: Jaume Miravitlles i Navarra, Gent que he conegut (Barcelona: Destino, 1979) y Més gent que he conegut (Barcelona: Destino, 1981); Mark Planellas-Witzsch, El somriure de Catalunya. Un retrat biogràfic de Jaume Miravitlles (Barcelona: Editorial Dux, 2008); Carles Fontserè, Memòries d'un cartellista català (1931-1939) (Barcelona: Editorial Pòrtic, 1995); Pilar Parcerisas Colomer, «L'ull de la fotografia moderna», en Pere Català-Pic: Fotografía y publicidad (Barcelona: Lunwerg / Fundació «La Caixa», 1998).
} 
la consecución de estos fines se dispuso el uso de la propaganda ya fuera escrita, hablada, gráfica, artística o deportiva. El decreto también establece la posibilidad de instituir delegaciones en el extranjero, tal como posteriormente se hizo en París, Estocolmo, Bruselas, Copenhague o Estados Unidos con la intención de poder favorecer el traslado a los medios internacionales de fotografías y boletines en catalán, castellano, francés, inglés, alemán y esperanto que decantasen la opinión pública en favor de la República. ${ }^{7}$

Al frente se puso a Jaume Miravitlles i Navarra, ${ }^{8}$ que había cosechado éxitos muy significativos como vicepresidente del Comitè Organitzador de la Olimpíada Popular, ${ }^{9}$ y, sobre todo, en el Comitè de Milícies Antifeixistes como Secretario General y representante de Esquerra Republicana de Catalunya (ERC). ${ }^{10}$ Miravitlles, según su testimonio personal, fue quien convenció al presidente Companys de los beneficios de crear una entidad de estas características en tiempos de guerra y quien redactó su decreto fundacional. ${ }^{11}$ Sólo en la Alemania nazi, la Italia fascista y la

\footnotetext{
${ }^{7}$ Decreto de creación del Comissariat de propaganda. Diari Oficial de la Generalitat de Catalunya de 5 de octubre de 1936, pág. 65.

${ }^{8}$ Jaume Miravitlles i Navarra (1906-1988). Nacido en Figueras se interesó desde muy joven por la política y el periodismo. Tuvo problemas con la justicia por participar en Els fets de Prats de Molló por los cuales se exilió en París donde coincidió con los escritores y artistas más vanguardistas de momento. Políticamente muy activo, militó en diferentes partidos: Estat Català, Bloc Obrer i Camperol y Esquerra Republicana de Cataluña. Próximo a Companys y Tarradellas ocupó diferentes puestos en representación de ERC y de la Generalitat hasta que finalmente fue nombrado Comissari de Propaganda. El 5 de febrero de 1939 cruzó la frontera con Francia junto a Companys para exiliarse en París y posteriormente en México y Estados Unidos, y no regresó a España hasta 1963. Llegó a publicar más de 10.000 artículos según Pascuet y Pujol (dirs.), La revolució del bon gust.

${ }^{9}$ La Olimpíada popular fue un acto alternativo a las Olimpíadas de Berlín que, en contraposición al carácter nazi de las mismas, fomentaba la unión de los pueblos, la dignidad humana y la paz. La inauguración de los juegos estaba programada para el día 19 de julio de 1936, pero a causa de alzamiento militar se suspendieron todos los actos y los atletas fueron repatriados.

${ }^{10}$ El Comitè de Milícies Antifeixistes se constituyó el 21 de julio de 1936 con representantes de ERC, CNT —Confederación Nacional del Trabajo_, UGT — Unión General de Trabajadores-, FAI - Federación Anarquista Ibérica-, ACR - Acció Catalana Republicana-, Unió de Rebassarires, PSUC - Partido Socialista Unificado de Cataluña-, POUM - Partido Obrero de Unificación Marxista- y de la Generalitat. Se creó con la finalidad de organizar militarmente Cataluña al tiempo que se le otorgaba protagonismo a los sindicatos y otras fuerzas revolucionarias con la intención de reconducir el caos que estas sembraban en las calles.

${ }^{11}$ Llúcia Oliva i de la Esperanza, «Mitjans de comunicació i memòria històrica. El Comissariat de Propaganda a través de la memòria dels que ho van viure», Treballs de Comunicació [Societat Catalana de Comunicació] 24 (2008): 3-53.
} 
Unión Soviética existían instituciones similares. Nos encontramos pues, ante la primera organización de este tipo en un país democrático occidental. Posteriormente fue tomada como modelo para otras instituciones tanto en España como fuera de ella.

El Comissariat fue, en cierta forma, la continuación de la Secció de Premsa, Ràdio i Propaganda que Miravitlles había dirigido en el Comitè de Milícies Antifeixistes. Ante la desarticulación del Comitè y de la sección que él dirigía, quiso asegurar la continuidad del Comissariat y su independencia; por ello insistió en que tuviera forma de Comisaría directamente dependiente de Presidencia y no de una concejalía que pudiera ser ocupada por políticos de signo diverso. ${ }^{12}$

Su financiación se realizó principalmente a base de créditos extraordinarios a disposición de Presidencia que entre diciembre de 1936 y enero de 1939 sumaron cerca de diez millones de pesetas, un coste excesivamente elevado según la opinión de quienes creían prioritario centrarse en la defensa armada antes que en la propaganda. ${ }^{13}$ Con el presupuesto asignado se debía mantener una plantilla que en algunos momentos llegó a los 300 empleados, la mayoría de ellos contratados directamente sin que mediase nombramiento o designación oficial. Este hecho, junto a la destrucción de documentos relativos al Comissariat por parte del servicio de Recuperación de Documentos, ${ }^{14}$ hace difícil conocer el número exacto de empleados en cada momento. ${ }^{15}$ Además del personal fijo, el Comissariat contó con el apoyo de toda la intelectualidad catalana y numerosos políticos de izquierdas tanto españoles como catalanes, muchos de los cuales colaboraron esporádicamente en sus publicaciones. Especialmente destacable es la estancia de Malraux y su equipo de filmación durante el rodaje de L'Espoir en la propia sede del Comissariat en la avenida Diagonal n. ${ }^{\circ} 442$ bis —entonces avenida 14 de abril— de Barcelona.

\footnotetext{
12 Batalla i Galimany, «Jaume Miravitlles i Navarra».

${ }^{13}$ Batalla i Galimany, «Jaume Miravitlles i Navarra».

${ }^{14}$ Tras la toma de Bilbao y a iniciativa del Cuartel General de Franco se creó el servicio «Recuperación de Documentos» con dependencia de la Oficina de Investigación y Propaganda Anticomunista, aunque con el tiempo llegaría a absorberla. Antonio González Quintana, «Fuentes para el estudio de la represión franquista en el Archivo Histórico Nacional, Sección Guerra Civil», Espacio, Tiempo y Forma. Serie V, Historia Contemporánea 7 (1994): 479-508.

${ }^{15}$ Daniel Venteo, «Primera noticia general del Comissariat de Propaganda de la Generalitat de Catalunya (1936-1939)», en La revolució del bon gust, dirs. Pascuet y Pujol, 31-134.
} 
Otros personajes destacados que llegaron a Cataluña durante la guerra y fueron atendidos $\mathrm{u}$ homenajeados por el Comissariat fueron, por ejemplo, Robert Capa, Gerda Taro, Ilya Ehrenburg, George Orwell, Norman Thomas o Errol Flynn.

La periodista Llúcia Oliva localizó en 2001 en el Archivo General de la Administración de Alcalá de Henares un organigrama con la estructura del Comissariat de Propaganda ${ }^{16}$ :

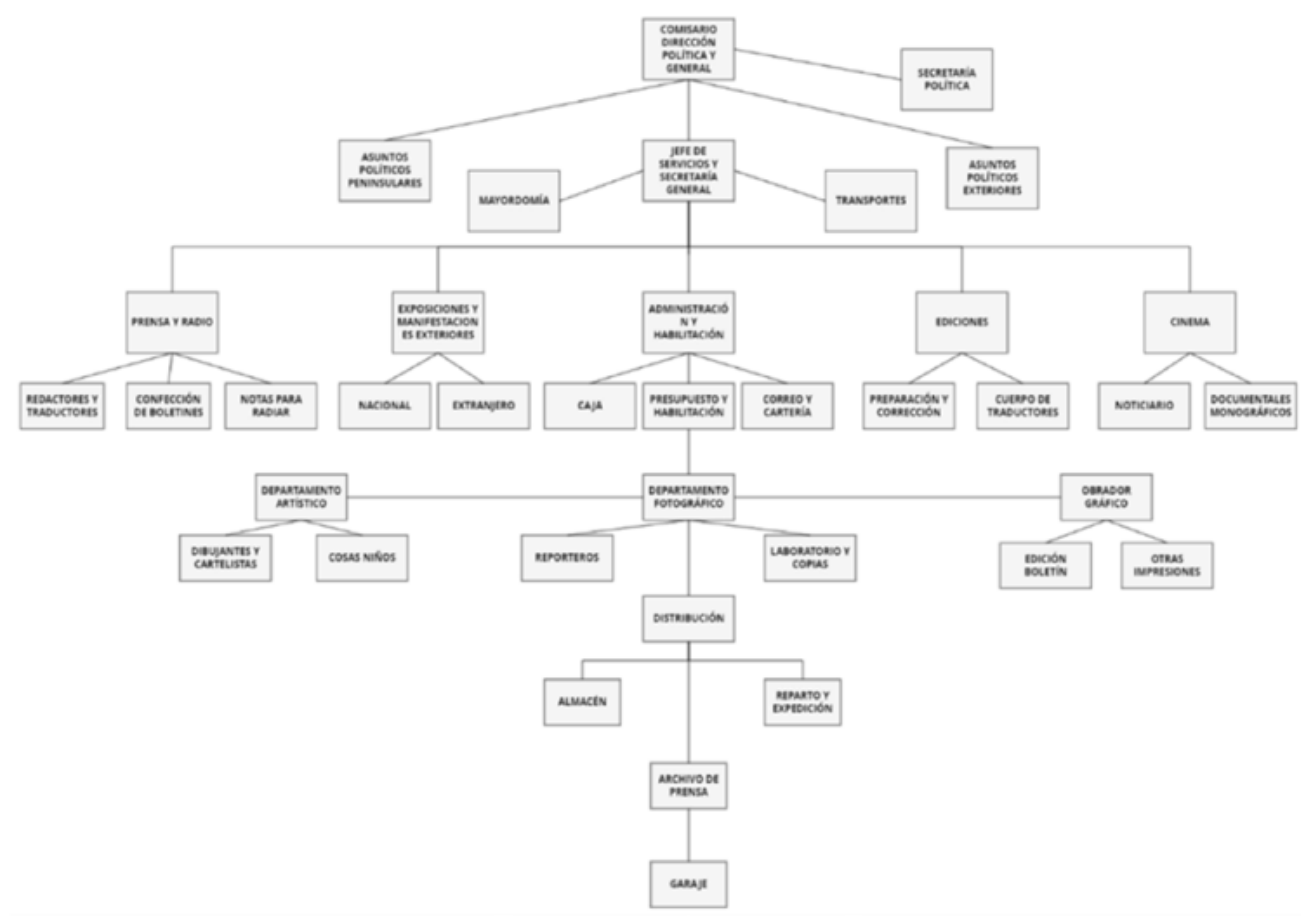

Imagen 1. Reproducción y traducción al castellano del Organigrama encontrado por Llúcia Oliva y que se puede consultar en Pascuet y Pujol (dirs.), La revolució del bon gust, 36.

En la estructura del Comissariat se incluyeron representantes de la UGT-PSUC, la CNT y hasta mayo de 1937 del POUM. ${ }^{17}$ Fueron muchos

\footnotetext{
${ }^{16}$ Oliva i de la Esperanza, «Mitjans de comunicació i memòria històrica».

${ }^{17}$ Batalla i Galimany, «Jaume Miravitlles i Navarra».
} 
los responsables de departamentos y secciones, amén de los colaboradores ocasionales. Entre los que ocuparon cargos de responsabilidad encontramos a Josep Sans Arrufat, Josep M. de Sucre, Miquel Coll i Alentorn, Ferran M. Ruiz-Hebrard, Josep M. Miracle, Nicolau M. Rubió i Turdurí, Marià Rubió i Tudurí, Josep M. Batista i Roca, Víctor Artís o Pere Català Pic.

Desde el Comissariat la propaganda era entendida como una herramienta positiva que no adolecía aún de la connotación peyorativa que hoy en día suele atribuírsele. Se consideraba un medio propicio para apoyar lo que se denominó como la «Revolució del bon gust». Esta expresión, que según el Comissari tomó prestada de un famoso escritor que no identifica, trataba de reflejar la idea de una revolución pacífica y tranquila totalmente diferente a otras precedentes que surgía de un sentimiento social y no «impulsada per la fam ni per la crisi, sinó per la defensa de l'esperit i de la dignitat. [...] Tenim ací un precedent magnífic d'allò que seria en països d'alta civilització - França, Anglaterra, Estats Units- un moviment d'alliberament social: l'alegria conscient, la bellesa en el viure ". ${ }^{18}$ Se estableció un plan de acción que incluía hasta 60 formas diferentes de publicitar las ideas y conceptos que favorecían esta causa. El título del documento que recoge estas estrategias es toda una declaración de intenciones: Plan de campanya publicitària per a la formació d'una psicosi instauradora de la Nova Iberia. ${ }^{19}$

La obra del Comissariat en sus escasos dos años y cuatro meses de existencia fue muy amplia e incluyó una importante labor editorial, artística, cinematográfica y radiofónica, así como de organización de exposiciones, conciertos, festivales y merchandising.

La Sección de Ediciones fue supervisada por el fotógrafo y publicista Pere Català Pic y el escritor Josep Roure-Torrent. Se calcula que unos 200 títulos vieron la luz, entre revistas de divulgación, cuadernos gráficos, boletines, hojas volantes, manifiestos, discursos institucionales y aucas.

\footnotetext{
${ }^{18}$ Jaume Miravitlles i Navarra, «El moment actual», Nova Iberia 1 (1937): s/p (edición en catalán).

${ }^{19}$ En el Archivo Nacional de Cataluña: Fondo Generalitat de Cataluña-Segunda República, se conserva el documento titulado «Plan de campanya publicitària per a la formació d'una psicosi instauradora de la Nova Iberia». Ha sido publicado en numerosas ocasiones; por ejemplo, se puede consultar en Solé i Sabaté y Villarroya i Font, Guerra i propaganda: fotografies del Comissariat.
} 
Muchas de estas obras fueron editadas en varios idiomas como castellano, francés, inglés, sueco e incluso esperanto. ${ }^{20}$

La literatura para niños ocupó un puesto especial con publicaciones infantiles como la colección Biblioteca Infantívola, Auca del noi Català Antifeixista i Humà, o Les pedres parlen. Fulls d'Història de Catalunya. La cultura generó publicaciones sobre arte y música. También se realizaron ediciones religiosas en un intento de desmontar la imagen anticlerical que los sublevados atribuían a los republicanos y mostrar respeto por la libertad religiosa. La guerra y su impacto en el día a día se vio reflejada en ediciones muy diversas, algunas dirigidas a los combatientes, como la revista Amic o el libro En dono fe... de A. Ruiz Vilaplana, además de otras dirigidas a toda la población en general. Autores nacionales y extranjeros dejaron su testimonio sobre la guerra en publicaciones del Comissariat. $^{21}$

La presencia en la radio del Comissariat se materializó a través de las numerosas intervenciones de Miravitlles, y de otros personajes destacados que visitaban Cataluña, en Ràdio Associació de Catalunya, ${ }^{22}$ desde donde también se retransmitían mítines, festivales, y otros programas. ${ }^{23}$ Alcanzaron gran popularidad las retrasmisiones sobre la actualidad en los frentes en las que participaban los propios soldados, así como las que hablaban sobre la vida en la retaguardia. La actividad radiofónica se mantuvo hasta el final de la guerra con emisiones diarias a las 16 y 20 horas. $^{24}$

La productora Laya Films, que nació en 1934 por iniciativa del Servei Cinematogràfic de la Conselleria de Cultura, pasó a formar parte, junto con Catalònia Films, del departamento de Cinema del Comissariat, a

\footnotetext{
${ }^{20}$ Venteo, «Primera noticia general del Comissariat».

${ }^{21}$ Una recopilación de la obra editorial la encontramos en Campillo, Escriptors catalans $i$ compromís; Pere Puig, «La revolució del bon gust. La guerra que es va guanyar»; Pascuet y Pujol (dirs.), La revolució del bon gust. y Figueres i Artigues, «El Comissariat de Propaganda de la Generalitat de Catalunya».

${ }^{22}$ Esta emisora y Radio Barcelona habían sido incautadas por la Generalitat mediante el decreto de 29 de Julio. Rosa Franquet i Clavet, Historia de la radiodifusió a Catalunya (del naixement al franquisme) (Barcelona, Edicions 62, 1986).

${ }^{23}$ Oliva i de la Esperanza, «Mitjans de comunicació i memòria històrica».

${ }^{24}$ Ester Boquera Diago, «El relevo en la propaganda oficial de la Guerra Civil española: de Jaume Miravitlles a Dionisio Ridruejo», Bulletin of Spanish Studies 89, no. 7-8 (2012): 187-199.
} 
cargo de Joan Castanyer. Contó con delegaciones en diferentes ciudades europeas, y fue responsable de un noticiario semanal, Espanya al dia, del que se produjeron cerca de 120 capítulos de los que se conservan sólo 16. ${ }^{25}$ Junto a las películas y documentales que trataban sobre la realidad de un país en guerra y los bombardeos sobre ciudades, se realizaron otros más cercanos a la tradición político-social catalana. Las instalaciones y medios técnicos también fueron aprovechados para ayudar a los cineastas extranjeros desplazados a Cataluña. Laya Films, que tenía la exclusiva del doblaje y distribución de los films soviéticos, también se encargó del doblaje al castellano y al catalán de las películas de vanguardia en Europa. ${ }^{26}$

La producción cartelística estuvo bajo el control de Francesc Fàbregas como director artístico. Su numerosa producción, la alta calidad de su obra y las innovaciones técnicas convirtieron la cartelería del Comissariat en un icono cultural. Este departamento contó con la colaboración de dibujantes tan destacados como Antoni Clavé, Carles Fontserè, Ricard Fàbregas, Josep Sala, Josep Subirats, Evarist Mora, Lola Anglada o Martí Bas. Con temáticas muy variadas, se realizaron carteles para campañas a favor del ejército regular, la defensa de Madrid, la ayuda a los refugiados, carteles institucionales para otros departamentos de la Generalitat, campañas de sensibilización o anunciadores de iniciativas propias del Comissariat como sus películas y revistas. $^{27}$

La fotografía fue otra de las herramientas utilizadas por el Comissariat. Como pruebas irrefutables de las atrocidades de la guerra y de los excesos de los fascistas, fueron enviadas a personajes destacados como el Papa, Hitler o Mussolini. También eran enviadas a los medios de comunicación extranjeros y estamentos oficiales como embajadas, gobiernos, etc. En la sede del Comissariat se montó un laboratorio de revelado y de reproducción para poder proveer copias suficientes. Estas instalaciones fueron utilizadas por fotógrafos extranjeros des-

\footnotetext{
${ }^{25}$ Joaquim Romaguera i Ramió, «Els noticiaris d'actualitat en el cinema espanyol», Treballs de comunicación 7 (1996): 41-52, y Pere Fages, «Laya Films, una propaganda de cine», en La revolució del bon gust, dirs. Pascuet y Pujol, 112-113.

${ }^{26}$ Batalla i Galimany, «Jaume Miravitlles i Navarra».

${ }^{27}$ Daniel Giralt-Miracle, «Els cartells del Comissariat: cultura informativa i modernitat», en La revolució del bon gust, dirs. Pascuet y Pujol, 108-109.
} 
plazados para cubrir la guerra y por reporteros locales. ${ }^{28}$ Las fotografías que sobrevivieron a la guerra y el exilio se conservan hoy en día en el Arxiu Nacional de Catalunya reunidas en 14 álbumes con un total de 5.539 imágenes. ${ }^{29}$ Por otra parte, las fotografías ocuparon un lugar destacado en la producción editorial del Comissariat con obras gráficas como la serie de fascículos Visions de guerra i reraguarda o la revista Nova Iberia, calificada por muchos como su obra más emblemática, al frente de la cual estuvo el fotógrafo, publicista y escritor Pere Català Pic.

Dentro de su política de apertura al exterior se organizaron varias exposiciones, como la celebrada en Paris en 1937 en el Jeu de Paume sobre arte catalán medieval o la de prensa catalana dentro de la Exposición Internacional de ese mismo año. Se organizó también una exposición itinerante con rótulos en castellano, francés, inglés y ruso. Era un canto a la resistencia republicana que, entre otras cosas, mostraba armamento italiano y alemán como muestra del apoyo de estos países a los golpistas. Se pudo visitar en diferentes capitales europeas y en México. ${ }^{30}$ En nuestro territorio destacan dos exposiciones. La primera de ellas Set mesos de guerra se pudo visitar primero en Barcelona y posteriormente en Madrid. La segunda, Madrid, un any de resistència heroica permaneció abierta durante dos meses en la Casa de la Cultura en una muestra de apoyo del pueblo catalán a la asediada Madrid. Aunque la organización dependió de la Subsecretaría de Propaganda del Ministerio de Estado, la ejecución fue del Comissariat que la llevo a cabo con la calidad técnica que caracterizaba todas sus empresas. $^{31}$

En su labor de movilización y concienciación de masas se promocionaron manifestaciones y movilizaciones populares, y se organizaron festivales, carreras y tómbolas benéficas. ${ }^{32}$ Incluso se llegaron a crear

\footnotetext{
${ }^{28}$ Una recopilación de estas fotografías se puede consultar en Solé i Sabaté y Villarroya i Font, Guerra i propaganda: fotografies del Comissariat.

${ }^{29}$ Merche Fernández Sagrera, «La fotografía i el Comissariat», en La revolució del bon gust, dirs. Pascuet y Pujol, 110-111

${ }^{30}$ Venteo, «Primera noticia general del Comissariat».

${ }^{31}$ Full Oficial del dilluns de Barcelona, 20 de diciembre de 1937.

${ }^{32}$ Full Oficial del dilluns de Barcelona, 31 de octubre de 1938.
} 
productos que hoy en día podríamos calificar de merchandising. El més petit de tots, por ejemplo, fue una figurita de unos 8 centímetros obra del escultor Miquel Paredes — habitual colaborador del Comissariat- que representaba un niño tocado por una gorra medio frigia, medio barretina, portando una bandera en la mano derecha mientras alzaba el puño izquierdo. Para su promoción se le encargó a Pere Quart que escribiese la letra de una canción que llevaría la melodía de la popular Els Tres Tambors. También se encargó a Lola Anglada un libro ilustrado sobre este personaje. La campaña tuvo tal éxito que se vendieron, dentro y fuera de Cataluña, entre doscientas y trescientas mil figuritas. ${ }^{33}$ Además, se creó la insignia Per Catalunya que se repartió gratuitamente entre los combatientes catalanes. Reproducía el emblema de la Generalitat y portaba la leyenda «Catalunya».

Explicar toda la obra del Comissariat en unas pocas páginas resulta imposible, tantas y tales fueron sus actividades. Aquí sólo hemos ofrecido una panorámica general de su labor. En ella debemos contextualizar la creación de la revista Nova Iberia de la que nos ocupamos a continuación.

\section{LA REVISTA NOVA IBERIA}

Bajo el título Nova Iberia. Revista mensual ilustrada el Comissariat publicó entre enero y marzo de 1937 la que es considerada por muchos la obra más emblemática de este organismo. ${ }^{34}$ En los números dos, tres y cuatro el subtítulo cambió a Publicación mensual Ilustrada. Su precio unitario era de tres pesetas y se podían contratar subscripciones a seis y doce meses por 18 y 36 pesetas respectivamente. ${ }^{35}$ Para unos Nova Iberia es una revista de arte y literatura; para otros se trata de una publicación institucional que intenta de ofrecer a la opinión internacional una imagen amable de la Generalitat y de sus esfuerzos por preservar la democracia, pero también de la idiosincrasia propia del pueblo catalán.

\footnotetext{
${ }^{33}$ Enric Pujol, «El més petit de tots», en La revolució del bon gust, dirs. Pascuet y Pujol, 66-67.

${ }^{34}$ Para saber más sobre Nova Iberia se puede consultar la bibliografía recomendada sobre el Comissariat de Propaganda, pero especialmente indicada es la lectura del capítulo que Maria Campillo en Escriptors catalans i compromís dedica a las publicaciones del Comissariat y sobre todo a esta revista.

${ }^{35}$ Campillo, Escriptors catalans i compromís.
} 
Guillamet afirma que la revista iba a ser usada como carta de presentación de la realidad catalana ante periodistas, gobiernos y representaciones extranjeras. ${ }^{36}$ La prensa de la época la definía como una revista que "reflectirà tots els aspectes de la nova estructuració de la vida». ${ }^{37}$ Una nueva estructuración en lo político y en lo social desde un punto de vista revolucionario.

Con una edición extremadamente cuidada, fue impresa en papel del alto gramaje y en formato folio mayor de $36 \times 26 \mathrm{cms}$. Su gran calidad técnica y plástica se debe en gran parte a su director. No en vano Pere Catala $\mathrm{Pic}^{38}$ en su periplo europeo había estado en contacto con la vanguardia fotográfica que en esos momentos experimentaba con técnicas como el picado, contrapicado, primeros planos, fotogramas, juegos de luces y sombras y fotomontajes. Ya en Cataluña experimentó con la mezcla de fotografía y dibujo, realizó estudios de publicidad, y se interesó por la ejecución altamente técnica para realizaciones de carácter artístico. ${ }^{39}$ La revista entronca con las vanguardias europeas en el diseño, la fotografía y el uso de la publicidad. Dentro de Cataluña recuerda al magazine D'Ací i d'Allà .

Apenas transcurrieron tres meses entre la creación del Comissariat y la aparición del primer número, por lo que podemos afirmar que nos encontramos ante uno de los primeros grandes proyectos de esta institución. En esos primeros meses de guerra la situación en Cataluña era complicada. Grupos revolucionarios tomaron el control de la calle y la Generalitat se vio obligada a negociar con comunistas, anarquistas, sindicalistas y otras fuerzas de izquierda un gobierno de concentración para recuperar el control del país. Como afirma Ramon Batalla i Galimany, la revolución había sido aceptada de facto, nadie dudaba ya de que era el camino a seguir en Cataluña, solo cabían dudas sobre la forma organizativa que debía tomar. ${ }^{40}$ En este contexto no

\footnotetext{
${ }^{36}$ Jaume Guillamet i Lloveras, «Jaume Miravitlles. Política, propaganda i periodismo», en La revolució del bon gust, dirs. Pascuet y Pujol, 235-244.

${ }^{37}$ Full oficial del dilluns, 579, 18 de enero de 1937.

${ }^{38}$ Para saber más recomendamos Pablo Giori, Pere Català Pic. Fotografia, publicitat, avantguarda $i$ literatura (1889-1971) (Barcelona: Rafael Dalmau, 2016).

${ }^{39}$ Merche Fernández Sagrera, «Pere Català Pic: fotografía i psicología publicitaria», en La revolució del bon gust, dirs. Pascuet y Pujol, 46-47

${ }^{40}$ Batalla i Galimany, «Jaume Miravitlles i Navarra».
} 
es de extrañar que la revista mantenga un tono claramente revolucionario. Desde el Comissariat se apostaba por una revolución tranquila y pacífica, pero inexorable: «Una revolució que un escriptor famós ha qualificat de la Revolució del bon gust, perquè s'ha fet sota el signe de l'esperit, perquè l'han feta uns homes que tenien molt a perdre: tot un patrimoni espiritual». ${ }^{41}$

El nombre de la revista era un homenaje a la revista Iberia publicada en Barcelona entre 1915 y 1919 en apoyo a los aliados de la I Guerra Mundial. Idea de un industrial francés, Iberia fue dirigida por Claudi Ametlla i Coll. Nova Iberia conservaba de su antecesora el carácter catalanista y republicano. Si la primera se publicó en castellano, catalán, francés y portugués, la de 1937 lo hizo, mediante ediciones simultáneas, en castellano, catalán, francés e inglés. Actualmente se puede consultar en diferentes bibliotecas y archivos dentro y fuera de España tales como la Hemeroteca Municipal de Madrid, la Biblioteca Nacional de España, la Biblioteca Nacional de Cataluña, el Centro Documental de la Memoria Histórica, la Fondation Maison des sciences de l'homme en París, la UC Berkeley Libraries o el Getty Research Institute de Los Angeles, por ejemplo. Su versión digital es accesible desde el Arxiu de Revistes Catalanes Antigues (ARCA) y en la Biblioteca Virtual de Prensa Histórica (BVPH). ${ }^{42}$

Se publicaron cuatro números en tres fascículos ya que el último de ellos incluía los números tres y cuatro. Contenía artículos escritos por políticos e intelectuales destacados como Dolores Ibarruri, Nicolau M. Rubió, Eduard Fontseré, Lluís Companys, Josep Tarradellas, Francesc Galí, Bosch Gimpera, Pompeu Fabra, Pere Català Pic, Carles Riba, Torres Clavé, Jaume Miravitlles, Alfons Maseras, Romain Rolland, Ramon Vinyes y Joan Puig Elias, entre otros. Además de la colaboración de personajes tan relevantes, el hecho de ocuparse de temas de actualidad incluyendo una gran cantidad de ilustraciones, mapas, gráficos y fotografías de excelente calidad, con un esmerado tratamiento en que cada artículo se presenta y con una compaginación y un estilo propios, convirtieron la

\footnotetext{
${ }^{41}$ Miravitlles i Navarra, «El moment actual» (edición en catalán).

42 Véase ARCA: http://mdc2.cbuc.cat/cdm/compoundobject/collection/novaiberia/id/8/rec/3 [último acceso 30-05-2017] y BVPH: http://prensahistorica.mcu.es/es/publicaciones/numeros_por_mes.cmd?idPublicacion=1001061 [último acceso 30-05-2017]
} 
revista en un éxito popular en el momento y en "producto emblemático» de propaganda. ${ }^{43}$

Algunos de los ilustradores que participaron son Antoni Clavé, Francesc Domingo, Joan Commeleran, F. Almuni, B. Santsalvador, Joaquim Serra i Sim o Josep Obiols. La mayoría de ellos firmaron sus aportaciones. En cambio, una gran parte de las fotografías aparecen sin rúbrica, incluyendo las de Pere Català, Gabriel Casas o Margaret Michaelis. Sin embargo, las imágenes aportadas por Josep Sala, antiguo director artístico de D'Ací i D'Allà, aparecen firmadas.

Cada uno de los tres fascículos publicados versa sobre un tema en forma de monográfico. El primero de ellos —enero de 1937 y portada de Antoni Clavé- en sus 38 páginas traza un dibujo de la actualidad y redefine la articulación política peninsular. En un primer momento puede parecer que sus artículos no guardan relación entre sí, pero un análisis detallado como el realizado por Campillo muestra cómo se analiza el impacto de la guerra en diferentes ámbitos como la política internacional, la economía, la sanidad, la ciencia, la literatura, el arte o el ejército. Este primer número parece trazar las líneas temáticas de los números siguientes. ${ }^{44}$

El número dos —febrero de 1937 y portada de Joan Commeleran-, con 42 páginas, se presenta en forma de monográfico dedicado a la sanidad y la asistencia social. Con la consecución de la autonomía la Generalitat inició una reforma de la asistencia social en busca de un sistema más justo y universal que no dependiese de la beneficencia y que alcanzara a cubrir toda la ciudadanía. En este número se entremezclan la exhibición de la obra realizada con los deseos —más intensos que nunca en este periodo revolucionario- de ofrecer una asistencia social y sanitaria personalizada según la tipología del usuario. La guerra, la revolución y la proyección internacional de Cataluña son temas recurrentes en todos los números de la revista que en este en concreto se visibilizan, por ejemplo, en artículos como «Els gasos de guerra i les indústries de pau», "Sota el signe dels bàrbars», "Catalunya i els refugiats», «Al servei del poble», «Nou concepte de l'assistència pública»

\footnotetext{
${ }^{43}$ Campillo, Escriptors catalans i compromís, 150.

${ }^{44}$ Campillo, Escriptors catalans $i$ compromís.
} 
o «Els hospitals i els serveis sanitaris davant la nova estructuració de Catalunya».

Los números tres y cuatro - marzo de 1937- fueron editados en un sólo fascículo. Sus 60 páginas se centran en diferentes aspectos de la vida cultural y educativa catalana tales como la obra cultural del ayuntamiento de Barcelona, las bibliotecas catalanas, el Institut d'Estudis Catalans, el patrimonio artístico y cultural de Catalunya, prestando una especial atención a la enseñanza. Sobre este número afirma Campillo que

el més interessant és la impressió travada i orgànica de l'activitat cultural que s'aconsegueix en presentar els seus diversos àmbits, des de veus prestigioses, en una perfecta combinació, pel que fa al tractament d'entitats i institucions, de tradició i d'obra renovadora, de solidesa i d'eficàcia social. ${ }^{45}$

En la contraportada del número de marzo se anuncia el quinto número como una monografia gràfica de la guerra actual. ${ }^{46}$ Prometía incluir fotografías de gran calidad que suplieran la escasa redacción por motivos de seguridad. Este número no llegó a publicarse. En mayo de 1937 Cataluña vivió el enfrentamiento violento entre las fuerzas del orden público de la Generalitat y los milicianos de la CNT, la FAI y otros grupos revolucionarios. Todo parece indicar que estos hechos interrumpieron la publicación de la revista Nova Iberia, que tenía preparado un quinto número que ya no llegó a salir. No debieron darse muchas explicaciones del porqué de esta interrupción, a juzgar por lo jocoso del comentario aparecido en un diario satírico cuatro meses después de la aparición del último número editado de esta revista, que rezaba «La revista mensual "Nova Iberia" es publicarà un mes no i un altre tampoc». ${ }^{47}$ Tampoco el testimonio de Miravitlles, recogido en entrevistas y obras autobiográficas, explica por qué, una vez restablecido el orden, no se continuó publicando la revista Nova Iberia.

\footnotetext{
${ }^{45}$ Campillo, Escriptors catalans i compromís, 152 (en catalán en el original).

${ }^{46}$ Nova Iberia, 3-4, marzo 1937.

${ }^{47}$ La Esquella de la torratxa, 6 de agosto de 1937.
} 


\section{NOVA IBERIA Y LA DIFUSIÓN GRÁFICA DEL REVOLUCIONARIO PROYECTO CATALÁN DE REFORMA ESCOLAR}

En el contexto revolucionario de los primeros meses de guerra, mediante decreto de 27 de julio de 1936 se creó el Comité —luego Consejo- de Escuela Nueva Unificada - a partir de ahora C.E.N.U.- El principal objetivo de este proyecto titánico era la organización de un nuevo sistema educativo nacional en Cataluña, basado en los principios racionalistas del trabajo y la igualdad social. Mediante la coordinación de todos los servicios de enseñanza - Estado, Ayuntamiento de Barcelona y Generalitat-, la incautación de escuelas confesionales y otros edificios, y la reestructuración de la gestión educativa en Cataluña, el C.E.N.U. consiguió crear 128.000 plazas escolares de las cerca de 150.000 que se calculaba necesarias para asumir el objetivo de escolarización total. El plan general de enseñanza estableció una educación básica entre 0 y 15 años, que incluiría diferentes escuelas —infantil, primaria, pre-aprendizaje, aprendizaje, escuelas del trabajo, y escuelas politécnicas-. Esta enseñanza básica posibilitaría el progreso de todos los alumnos independientemente de su origen social. Después seguirían las Escuelas Técnicas y la Universidad, así como las enseñanzas de Bellas Artes y Oficios. Todo este sistema sería gratuito, laico, coeducativo y en catalán. A pesar de los inconvenientes con los que topó este proyecto, marcados por el progreso del conflicto bélico, las diferencias entre sindicatos de la enseñanza, los ya mencionados hechos de mayo del 37 , la llegada masiva de refugiados — muchos de ellos niños- y el avance de las fuerzas sublevadas, el C.E.N.U. consiguió establecer el sistema educativo más moderno y avanzado de su época en la Europa occidental. ${ }^{48}$

El tercer y cuarto número de la revista Nova Iberia, publicados en marzo de 1937 conjuntamente en un único fascículo, se ocuparon de

\footnotetext{
${ }^{48}$ Sobre el C.E.N.U. se puede consultar, entre otras aportaciones, las siguientes: Enriqueta Fontquerni y Mariona Ribalta, L'ensenyament a Catalunya durant la Guerra Civil. El CENU (Barcelona: Editorial Barcanova, 1982); Ramon Navarro Sandalinas, L'educació a Catalunya durant la Generalitat. 1931-1939 (Barcelona: Edicions 62, 1979); Mariona Ribalta, «Una proposta educativa global i innovadora: el C.E.N.U: (Consell d'Escola Nova Unificada)», Educació i Història 1 (1994): 125-129; Mercè Rossell (ed.), La Generalitat de Catalunya II. La política cultural (Barcelona: Undarius, 1977); y Ramón Safón, La educación en la España revolucionaria (1936-1939) (Madrid: La Piqueta, 1978); Pere Solà i Gussinyer, Educació i moviment llibertari a Catalunya (1901-1939) (Barcelona: Edicions 62, 1980); y Alejandro Tiana Ferrer, Educación libertaria y revolución social: España 1936-1939 (Madrid: UNED, 1987).
} 
manera monográfica del tema de la educación y la cultura en Cataluña, dando difusión nacional e internacional a este revolucionario proyecto de reforma escolar que se estaba llevando a cabo.

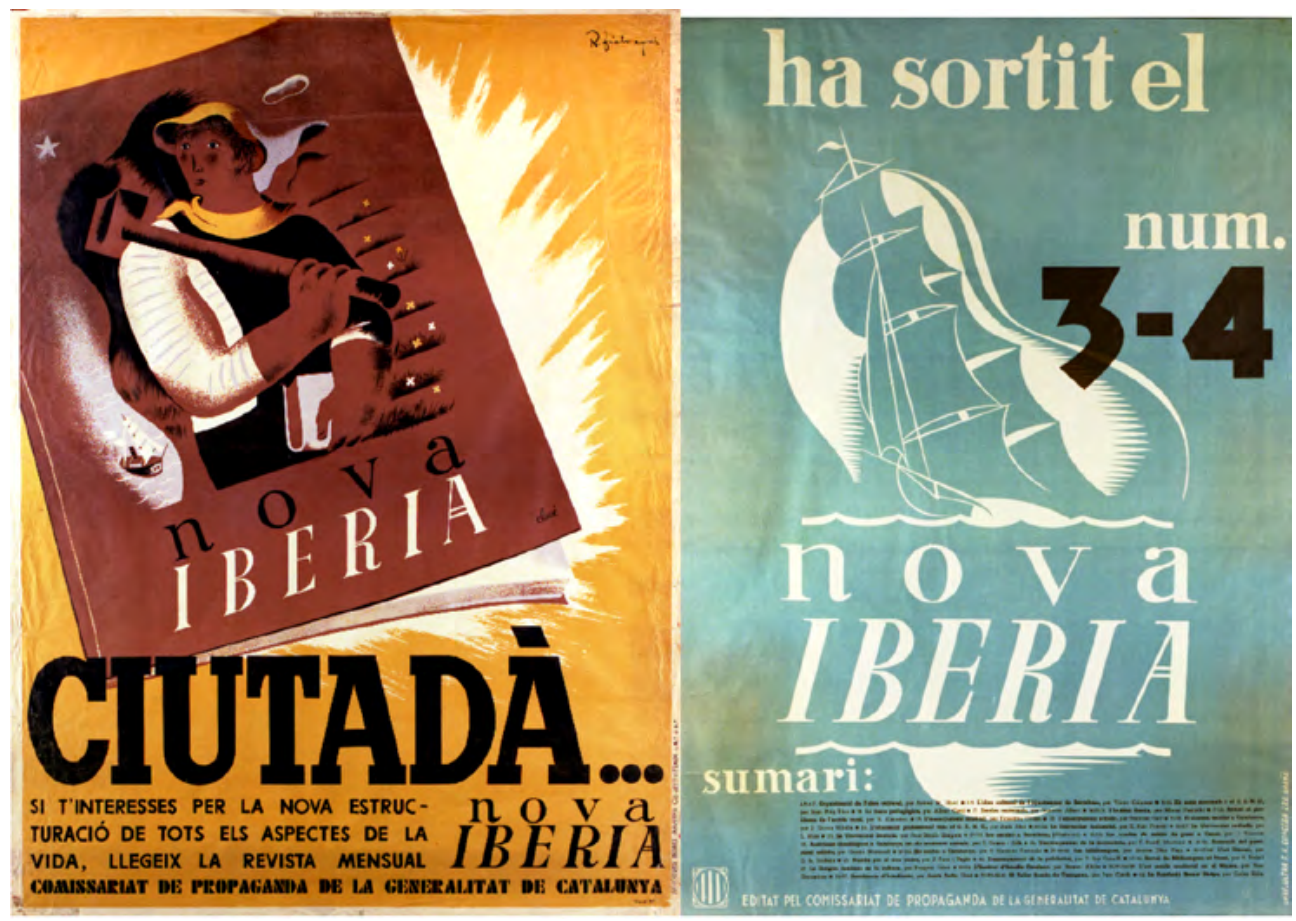

Imágenes 2-3. Pósteres publicitarios de Nova Iberia. Procedencia: Pavelló de la República (Universitat de Barcelona)

Como en los dos números anteriores, éste contiene numerosas fotografías de gran calidad e ilustraciones de artistas renombrados como el de la misma portada, de Francesc Domingo. Incluye 30 artículos, firmados en su mayoría por personalidades de reconocido prestigio, que tratan sobre enseñanza, cultura, y patrimonio cultural. El total de fotografías incluidas es de 51. Esta cifra puesta en relación con el número de artículos es representativa de la importancia que se otorga a la fotografía en esta publicación. 


\section{Estos artículos son:}

\begin{tabular}{|c|c|c|}
\hline Título & Autor & $\begin{array}{l}\text { Número de } \\
\text { fotografías }\end{array}$ \\
\hline Organización de la obra cultural & Antoni M. ${ }^{a}$ Sbert & - \\
\hline La obra cultural del Ayuntamiento de Barcelona & Víctor Colomer & 3 \\
\hline Los niños anormales y el CENU & Joan Puig Elias & 1 \\
\hline La Labor Pedagógica. La Escuela Nueva Unificada & Albert Carsi & - \\
\hline Escuelas maternales & Francesc A. Marrugat & 2 \\
\hline El Instituto Escuela & Marçal Pascuchi. & 4 \\
\hline En torno al problema de la Escuela Rural & Herminio Almendros & - \\
\hline La enseñanza musical en el CENU & Ernestina Corma & 1 \\
\hline La enseñanza artística en la Escuela Nueva Unificada & Francesc Galí & - \\
\hline El cine escolar en Cataluña & Josep Carner Ribalta & 2 \\
\hline La orientación profesional dentro del CENU & Joan Aleu Boxaca & - \\
\hline La enseñanza técnico industrial en Cataluña & $\begin{array}{l}\text { Estanislau Ruiz } \\
\text { Ponseti }\end{array}$ & 4 \\
\hline La universidad radiada de Cataluña & E. Mira & 2 \\
\hline La Universidad hogar de la Cultura & Pere Bosch Gimpera & 1 \\
\hline $\begin{array}{l}\text { La escuela de géneros de punto de la Generalitat de } \\
\text { Cataluña en Canet de Mar }\end{array}$ & $\begin{array}{l}\text { Joaquim Torrens- } \\
\text { Ibern }\end{array}$ & 3 \\
\hline $\begin{array}{l}\text { Actividades científicas en Cataluña en los momentos } \\
\text { actuales }\end{array}$ & Josep Comas i Solà & - \\
\hline Preparación técnica de la burocracia & E. Rosell y Montané. & - \\
\hline Las bibliotecas catalanas & Aurora Diaz Plaja & 3 \\
\hline La protección del patrimonio artístico nacional & Jeroni Martorell & 2 \\
\hline Los archivos de Cataluña & $\begin{array}{l}\text { Ernest Martínez } \\
\text { Ferrando }\end{array}$ & 3 \\
\hline El arte literario en la Cultura Catalana & C. A. Jordana & - \\
\hline Rumbos para el nuevo teatro & Josep Pous i Pagès & - \\
\hline La enseñanza de la Publicidad & Pere Prat Gaballí & - \\
\hline Servicio de Bibliotecas del frente & Francisco Trabal & 2 \\
\hline El idioma catalán en la cultura & Pompeu Fabra & - \\
\hline El Instituto de Estudios Catalanes & Ramon D'Alòs & 3 \\
\hline Residencia de Estudiantes & Josepa Barba Gosé. & 3 \\
\hline El arte catalán medieval en el museo & Pere Corominas & 4 \\
\hline El Taller Escola de Tarragona & Pere Català & 7 \\
\hline La Fundació Bernat Metge & Carles Riba & 1 \\
\hline
\end{tabular}


Cada uno de ellos ilustra con fotografías o con algún dibujo, diferentes aspectos tanto del panorama escolar y cultural de Cataluña al inicio de la Guerra Civil, como de los proyectos o planes de futuro más inmediato en este ámbito. Pero su propósito no es sólo el de informar, documentar u ofrecer una crónica objetiva de lo que estaba sucediendo a nivel educativo en Cataluña durante ese primer año de guerra, sino sobre todo publicitar, dentro y fuera de Cataluña, la revolución social que se estaba llevando a cabo y legitimarla ante la opinión pública.

En uno de los artículos de este mismo monográfico, dedicado a la enseñanza de la publicidad, se destaca precisamente la importancia que se le da en ese momento a la propaganda como herramienta capaz de «en horas de revolución y de reconstrucción [...] saber orientar acertadamente los espíritus tocando con precisión sugestiva la razón y el sentimiento público ${ }^{49}$. El tema genérico elegido para este monográfico, así como la forma de tratarlo y de ilustrarlo con fotografías y dibujos, está más orientado a proyectar una imagen idealizada de Cataluña como nación en plena revolución cultural, social, educativa y cívica, que no a mostrar el día a día de una sociedad inmersa en un conflicto bélico. Se trata de representar iconográficamente una idea de revolución lo más alejada posible de la violencia o la barbarie, pues no hay que olvidar que en esos momentos la Europa occidental y democrática temía el avance del fascismo, pero también el del comunismo y el anarquismo, que asociaban con la Revolución Rusa. Por ello desde el Comissariat interesaba hacer visibles sus modernos y avanzados proyectos educativos y culturales por encima de otras cuestiones, pues esto ayudaba a legitimar su lucha a nivel internacional.

Las fotografías, de gran tamaño y calidad, ocupan un lugar preeminente en la revista. Su objetivo es reforzar, mediante el impacto visual, este discurso revolucionario y otorgarle la veracidad que inspira la fotografía. La gran mayoría no aportan información adicional que nos permita identificar autor, fecha o incluso lugar. Algunas incluso parecen no tener relación directa con el texto. Por ello, debemos analizarlas en su conjunto, y en relación con el mensaje escrito tanto general, como de cada artículo en particular. Al no tener un claro objetivo documental, la

\footnotetext{
${ }^{49}$ Pere Prat Gaballí, "La enseñanza de la Publicidad», Nova Iberia 3-4, marzo de 1937, s/p (edición en castellano).
} 
imagen se usa aquí con el mismo propósito que el texto, para construir un discurso utópico que pretende legitimar los proyectos educativos de la Cataluña revolucionaria, y su transcendencia en la construcción de una nueva sociedad. El objetivo no es informar, sino convencer. No se trata de fotoperiodismo, sino de propaganda.

Utilizar la representación fotográfica de la escuela en todos sus ámbitos con fines propagandísticos tampoco era algo nuevo. A partir de inicios del siglo xx y durante las décadas posteriores la renovación pedagógica sirvió al regeneracionismo noucentista para promover un amplio programa modernizador en Cataluña, que, desmarcándose del Estado Español, legitimaba el papel de la educación y de la escuela en la construcción de una nueva sociedad liberal y democrática. Las ideas de la Escuela Nueva y de la escuela progresista norteamericana fueron las que dieron fundamento a este proyecto. En ese contexto, ya se hizo un uso propagandístico de la fotografía escolar. Un ejemplo claro lo tenemos en los numerosos reportajes gráficos sobre la aplicación de métodos como el de Montessori, ${ }^{50}$ o en la colección de libros ilustrados que editó el Ayuntamiento de Barcelona para publicitar su obra pedagógica. ${ }^{51}$

Nova Iberia utiliza de nuevo, aunque con la intención de legitimar un orden social diferente, la fotografía escolar - tanto de instituciones y/o experiencias ya existentes y ahora renovadas, como de nuevas creadas con el inicio de la revolución- para proyectar la idea de modernización pedagógica.

Se sirve para ello de elementos iconográficos ya conocidos, como el juego, el movimiento, la libertad, el autogobierno, los espacios libres, la higiene, etc. No obstante, incorpora otros menos habituales en las fotografías publicadas en años anteriores, que ayudan a construir un discurso más cercano al ideario pedagógico de los sectores que defendían la revolución social, y con ella la escuela única y para todos, basada en los principios racionalistas del trabajo.

\footnotetext{
${ }^{50}$ Francisca Comas Rubí y Bernat Sureda Garcia, «The photography and propaganda of the Maria Montessori method in Spain (1911-1931)», Paedagogica Historica 48, no. 4 (2012): 571-587.

${ }^{51}$ Sara González Gómez, Francisca Comas Rubí y Bernat Sureda Garcia, «La renovación escolar del Ayuntamiento de Barcelona y su difusión fotográfica (1908-1936)», Revista Española de Pedagogía [aceptado para su publicación].
} 
Veamos algunos ejemplos de lo que estamos diciendo. He aquí una de las fotografías que publica este número:

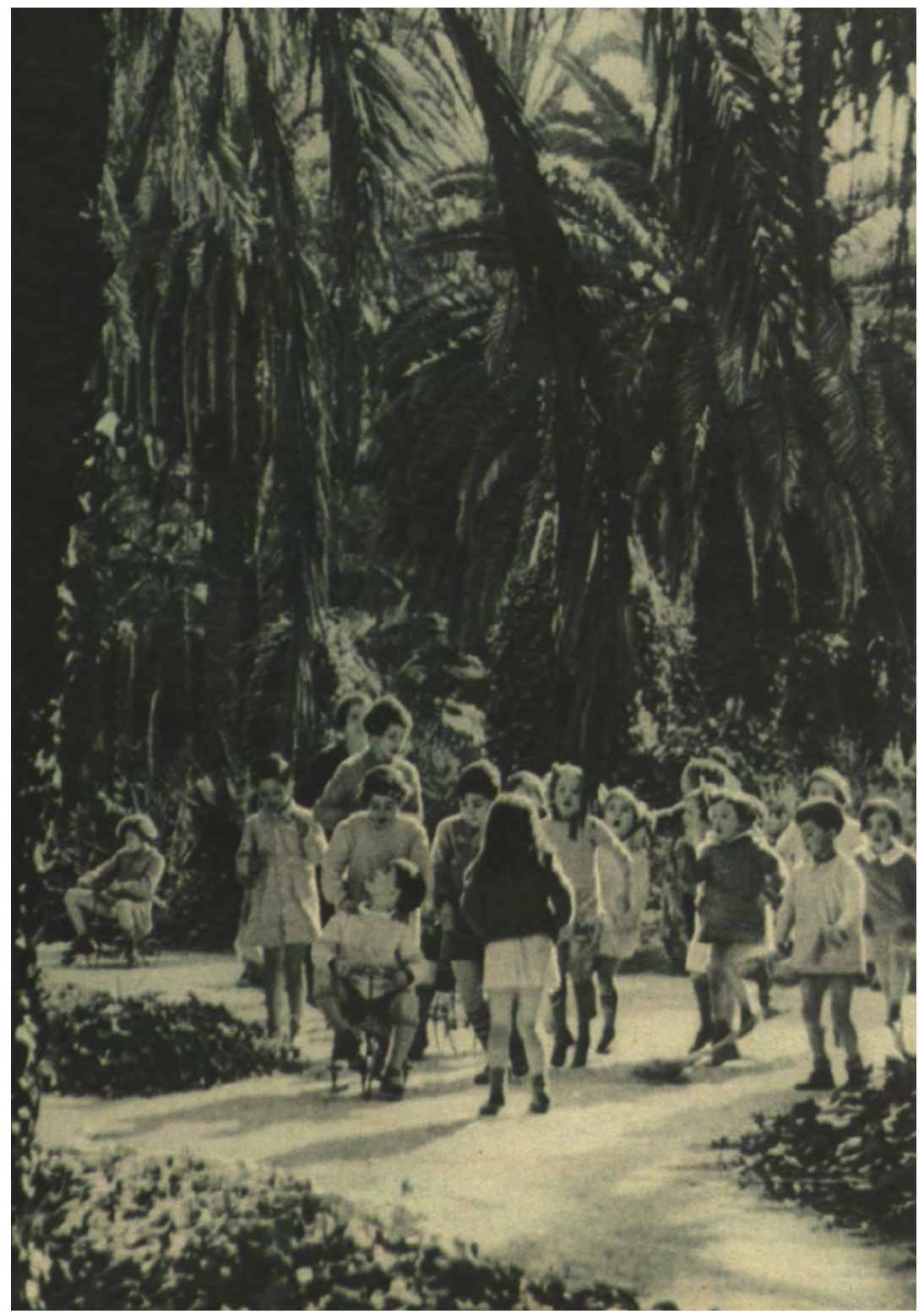

Imagen 4. Fotografía incluida en el artículo de Joan Puig Elias, «Los niños anormales y el CENU», Nova Iberia 3-4, marzo de 1937, s/p. 
Los elementos visuales que aparecen en esta imagen hacen referencia al juego, autonomía, espacios libres, naturaleza, movimiento y felicidad. Los niños parecen estar en un jardín jugando animadamente bajo la supervisión de un adulto, posiblemente la maestra, que apenas se hace visible. Sólo la bata los relaciona con la escuela. La fotografía se incluye en un artículo de Puig Elias sobre los niños anormales y el C.E.N.U. ${ }^{52}$ Pero lo cierto es que ningún elemento los identifica a priori como niños anormales, abarcando en esa época bajo esta denominación un amplio abanico de características particulares -deficiencias, minusvalías físicas y/o psíquicas, enfermedades, etc.- . Esto resulta curioso. El artículo no habla de cómo el C.E.N.U. atiende a estos niños, sino de cómo debería hacerlo. Se trata de un proyecto de futuro que aún no se puede ilustrar con fotografías, así que para ello se elige una imagen escolar exterior, en la que predomina el juego, la libertad, el movimiento, la naturaleza, el aire libre, y la autonomía de los niños.

Otra imagen que tampoco pasa desapercibida es la que se usa en el artículo sobre la enseñanza musical en el C.E.N.U. Se trata de una fotografía a media página, a la que seguirá el texto escrito, en la que se ve a una maestra tocando el piano ante la atenta mirada de sus alumnos, niños y niñas que se agolpan junto a ella.

Ningún elemento iconográfico en esta imagen se asocia con una enseñanza de la música basada en el solfeo y la teoría musical, que eran las materias más tradicionales. La belleza de la música es suficiente para atraer la atención de los más pequeños, que parecen no sólo escucharla, sino también sentirla. A pesar de que en el texto se puede leer la siguiente afirmación: «Desvetllar en l'infant la necessitat de sentir la música i cantar-la amb tota devoció: tal és el pla bàsic musical de les escoles del C.E.N.U.», ${ }^{53}$ no cabe duda de que en esta ocasión la fotografía transmite esta idea con mucha más fuerza.

Otras imágenes escolares, aun siendo estéticamente más tradicionales, ayudan siempre a crear este discurso visual optimista y positivo

\footnotetext{
52 Joan Puig Elias, «Los niños anormales y el CENU», Nova Iberia 3-4 (1937) s/p.

${ }^{53}$ Ernestina Corma, «La enseñanza musical en el CENU», Nova Iberia 3-4 (1937), s/p (edición en catalán)
} 
sobre la nueva idea de escuela en Cataluña. Un buen ejemplo son las fotografías que ilustran el artículo sobre la obra cultural del Ayuntamiento de Barcelona.

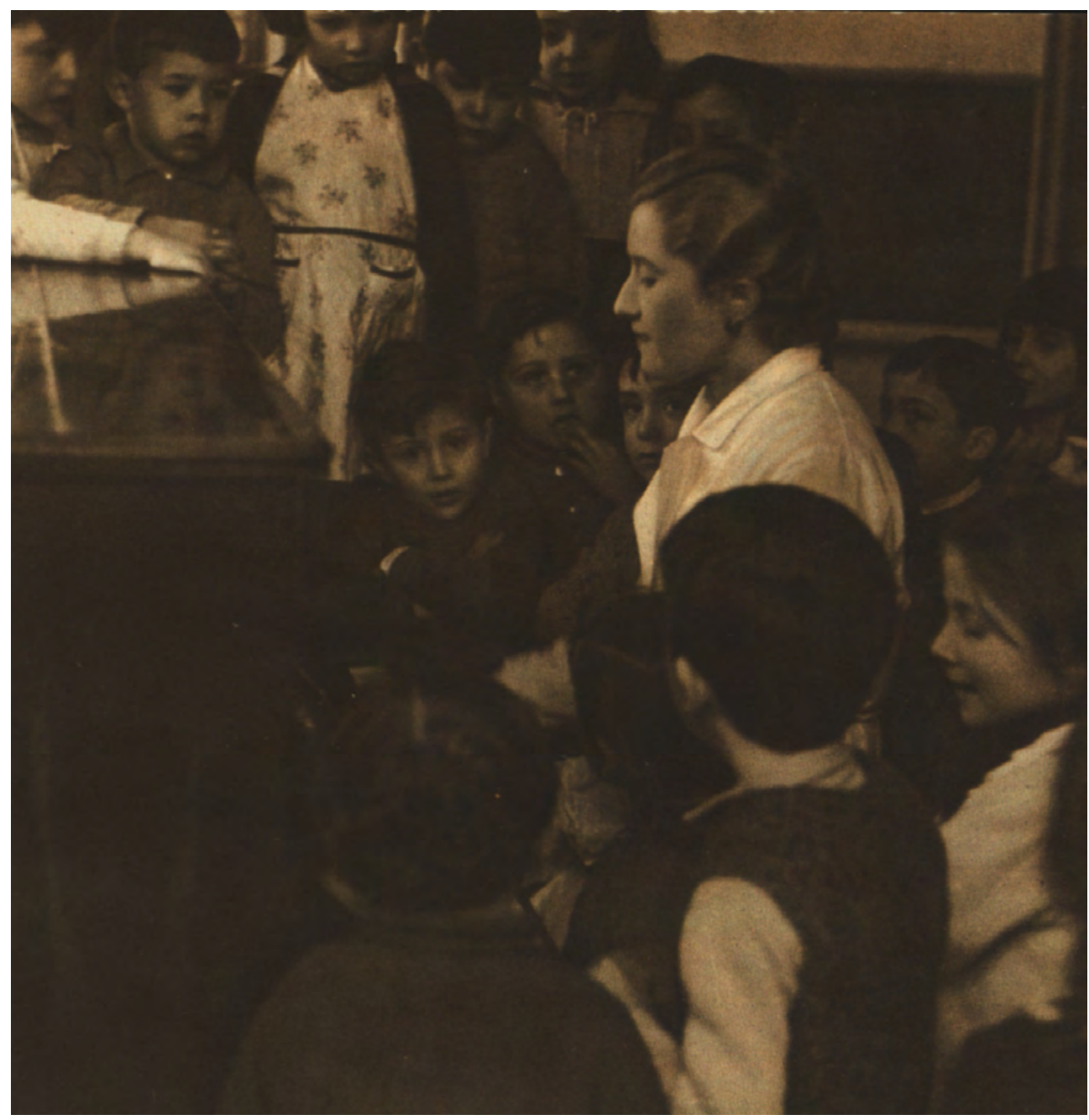

Imagen 5. Fotografía incluida en el artículo de Joan Aleu Boxaca, «La orientación profesional dentro del CENU», Nova Iberia, 3-4, marzo de 1937, s/p 
El texto se muestra muy crítico con la política educativa llevada a cabo por el Ayuntamiento durante las décadas anteriores, así como con la creación y labor del Patronato Escolar municipal. Las escuelas y experiencias dinamizadas por el Ayuntamiento se consideran loables, pero elitistas, lo que justifica una política revolucionaria que extienda esta obra a toda la población. Las imágenes que ilustran este artículo contienen elementos iconográficos que el lector puede asociar a la idea de modernización educativa, como la decoración del aula - hay flores sobre las mesas-, la presencia de juguetes y materiales escolares, la felicidad de los niños o la no autoridad de la maestra, que o bien está en un claro segundo plano o está ayudando en las tareas escolares como una guía y no como una autoridad en el aula. A pesar de que el artículo critica que la tarea realizada por el Ayuntamiento de Barcelona antes de la Guerra Civil no consiguiera llegar a toda la población, y explica los planes actuales de "crear uns grups d'assaig que seran una mena de centres d'inquietud pedagògica renovadora. Seran practicats per mestres experts i entusiastes, els mètodes Dalton, Decroly, Freinet, Cousinet, Projectes de l'Escola del Treball i de l'Escola», ${ }^{54}$ estas dos fotografías publicadas podrían pertenecer perfectamente a épocas anteriores, pues su objetivo no es ni reflejar la crítica ni ilustrar los planes de futuro, sino reforzar el discurso iconográfico de modernización pedagógica que se mantiene a lo largo de las páginas de la revista.

Algo parecido ocurre con las fotografías que acompañan el artículo de las escuelas maternales, que ya existían en Cataluña antes de la Guerra Civil. Las imágenes que se incluyen en el artículo en cuestión no son muy diferentes de las que se habían publicado en la prensa ilustrada con anterioridad; incluso de las publicadas por Nova Iberia en su número anterior. Son muy parecidas, por ejemplo, a las de las guarderías creadas por el Segell Pro Infancia durante la II República para la prevención de la tuberculosis, de las que Nova Iberia hace difusión en su número dedicado a la asistencia social en Cataluña. ${ }^{55}$

\footnotetext{
${ }^{54}$ Víctor Colomer, «La obra cultural del Ayuntamiento de Barcelona», Nova Iberia 3-4 (1937), s/p (edición en catalán).

${ }^{55}$ Avelina Miquel Lara y Francesca Comas Rubí, «La representación gráfica de la obra educativa del Segell Pro Infància en Cataluña», en Espacios y patrimonio histórico-educativos, dirs. Paulí Dávila Balsera y Luis María Naya Garmendia (Donostia: Erein, 2016), 813-823.
} 

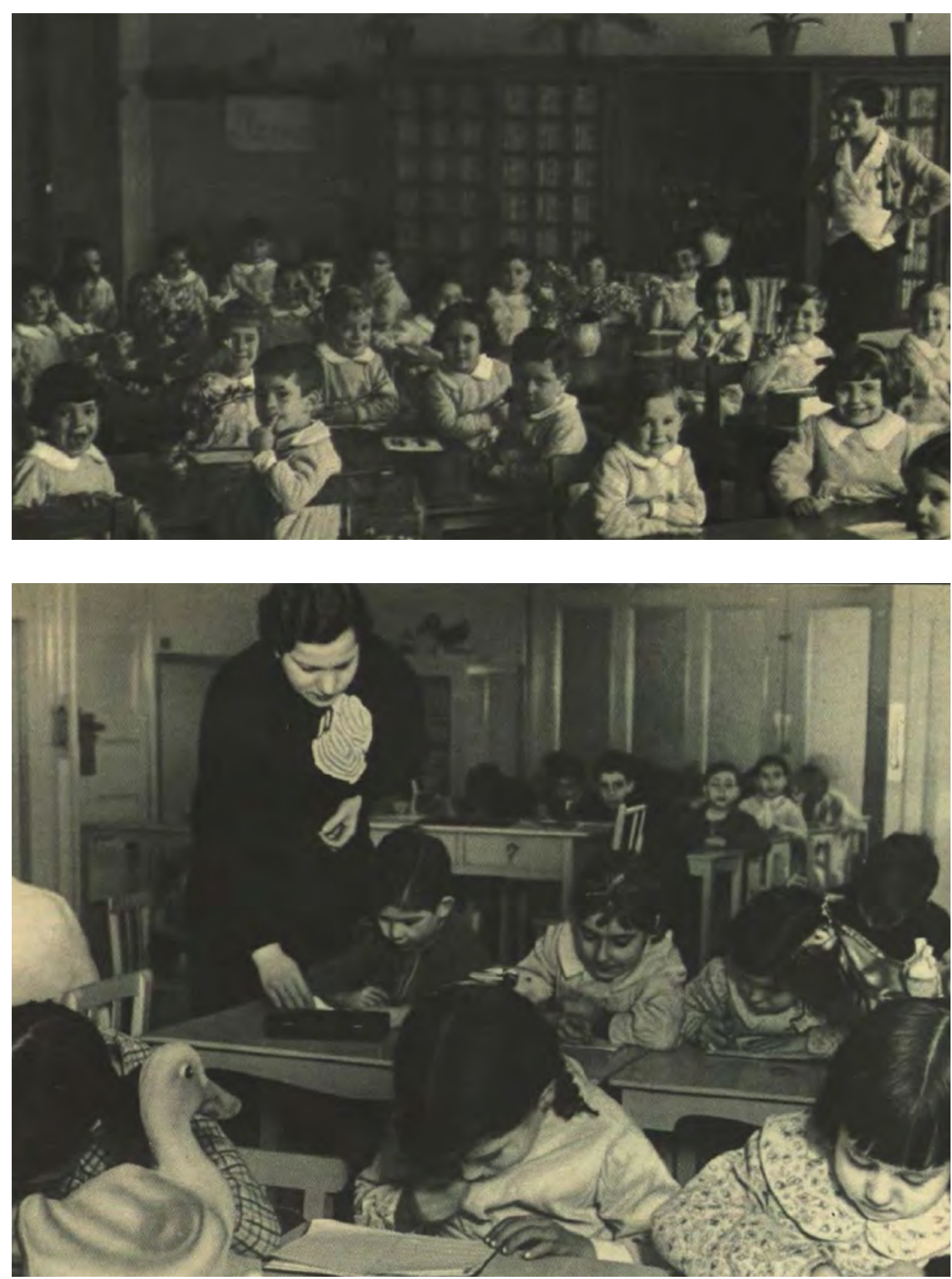

Imágenes 6-7. Fotografías incluidas en el artículo de Víctor Colomer, «La obra cultural del Ayuntamiento de Barcelona», Nova Iberia 3-4, marzo de 1937, s/p. 

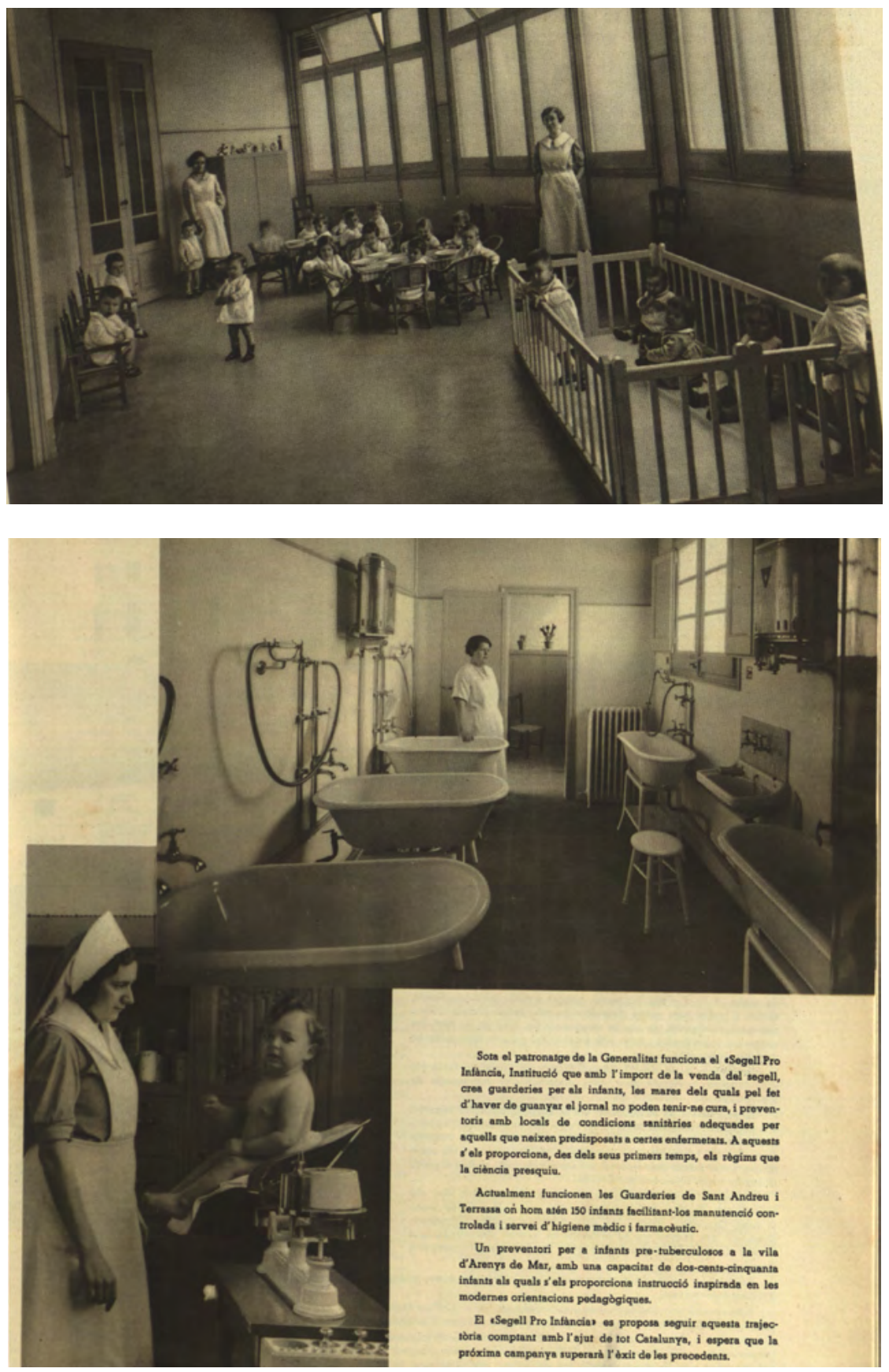

Imágenes 8-9. Fotografías incluidas en el artículo de Antoni Alier Torrents, «Segell Pro Infancia», Nova Iberia 2, febrero de 1937, s/p. 
Pero, a diferencia de esas, la interpretación que el lector pueda hacer de las fotografías incluidas en este monográfico sobre educación y cultura cambia sensiblemente por dos razones: en primer lugar, por estar incluidas en monográficos distintos unas parecen incidir más en la idea socio-sanitaria mientras que otras lo hacen más en la socio-educativa; en segundo lugar, las fotografías de un artículo y otro construyen discursos visuales sensiblemente diferentes que los textos que las acompañan acaban de reforzar. Las fotografías incluidas en el monográfico sobre enseñanza, a diferencia de las que ilustran el número anterior, pretenden transmitir la idea de que las enfermeras puericultoras no sólo cuidaban de la salud física de los niños de forma afectiva y maternal, sino también de su educación. Por ello combinan una imagen de una enfermera puericultora dando el biberón a un niño en lo que parece ser una enfermería —en la parte superior - con la de dos enfermeras puericultoras cuidando a un grupo de niños mientras juegan en un parque infantil situado en el exterior.

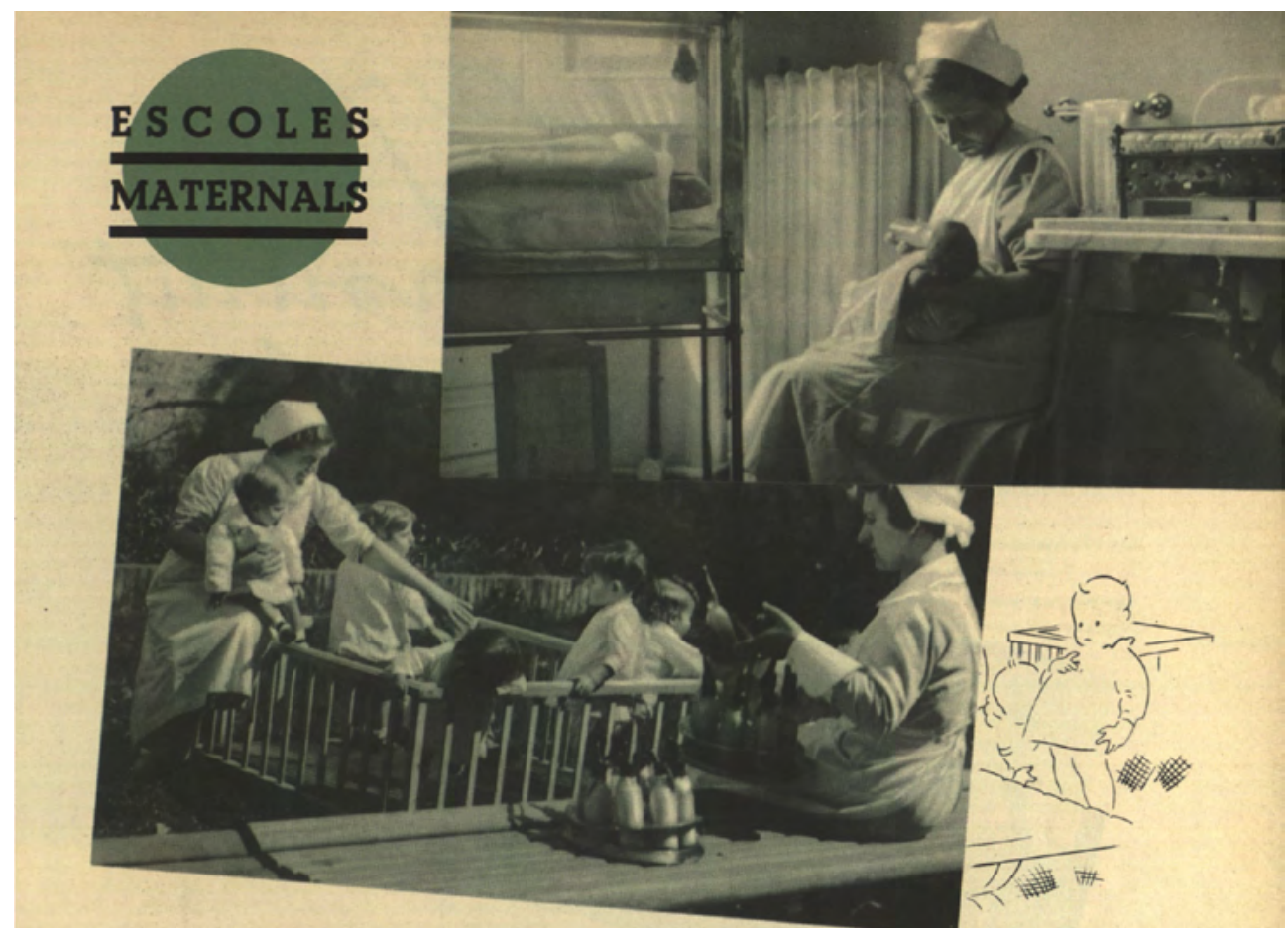

Imagen 10. Fotografías incluidas en el artículo de Francesc Albert,

«Escoles maternals», Nova Iberia 
La elección de las fotografías, su disposición en la publicación, la combinación entre ellas, o el texto que las acompaña, son factores que influyen en la construcción de su particular discurso y que pueden influir en la percepcion del lector.

A la ya conocida iconografía de la modernización educativa divulgada en los años anteriores, Nova Iberia incorpora dos elementos propios del discurso revolucionario: la socialización de esta renovación pedagógica, y la incorporación en ella del trabajo productivo como elemento de una educación racionalista.

En cuanto a la idea primera, de publicitar una escuela nueva y moderna al alcance de toda la sociedad, resulta interesante una mirada atenta a la composición fotográfica que se hace en la primera página del artículo sobre los Institutos-Escuela. Se trata de dos fotografías sobre enseñanza de la música que aparentemente podrían parecer contrapuestas, pero que más bien se complementan con el objetivo crear el discurso deseado.

En la fotografía situada en la parte superior se ve un grupo de chicas jóvenes junto a un profesor de música al piano, realizando un cuadro plástico propio del método de enseñanza de la música por el ritmo creado por Jaques Dalcroze, e introducido durante el primer tercio del siglo xx en Cataluña por Joan Llongueras. Llama la atención que se incluya esta imagen, pues este método, que tuvo una gran difusión en la Cataluña del Noucentismo, había sido impulsado por las mismas clases políticas que tanto se critican en los textos, y reprobado, sobre todo durante la II República, por ser caro y elitista. ${ }^{56}$ Aun así, Nova Iberia publica una imagen claramente identificable con la práctica dalcroziana, y posiblemente, dada la naturaleza de la revista, su inclusión no sea casual. La fotografía se superpone ligeramente a otra imagen de en la que se aprecia un auditorio muy numeroso de niños y niñas sentados que observan como un compañero toca el violín acompañado de un adulto al piano bajo la atenta mirada del maestro. Parece tratarse de una audición. La fotografía de la práctica dalcroziana, que aparentemente puede parecer contradictoria con el discurso revolucionario, adquiere sentido en relación con esta otra imagen. Juntando las dos fotos de enseñanza musical parece que se pre-

\footnotetext{
${ }^{56}$ Francisca Comas Rubí y Bernat Sureda Garcia, «Pedagogical innovation and music education in Spain: Introducing the Dalcroze method in Catalonia», Paedagogica Historica 50, no. 3 (2014): 320-337
} 
tenda combinar lo exclusivo con lo masivo, de socializar y democratizar lo que hasta entonces se consideraba elitista.

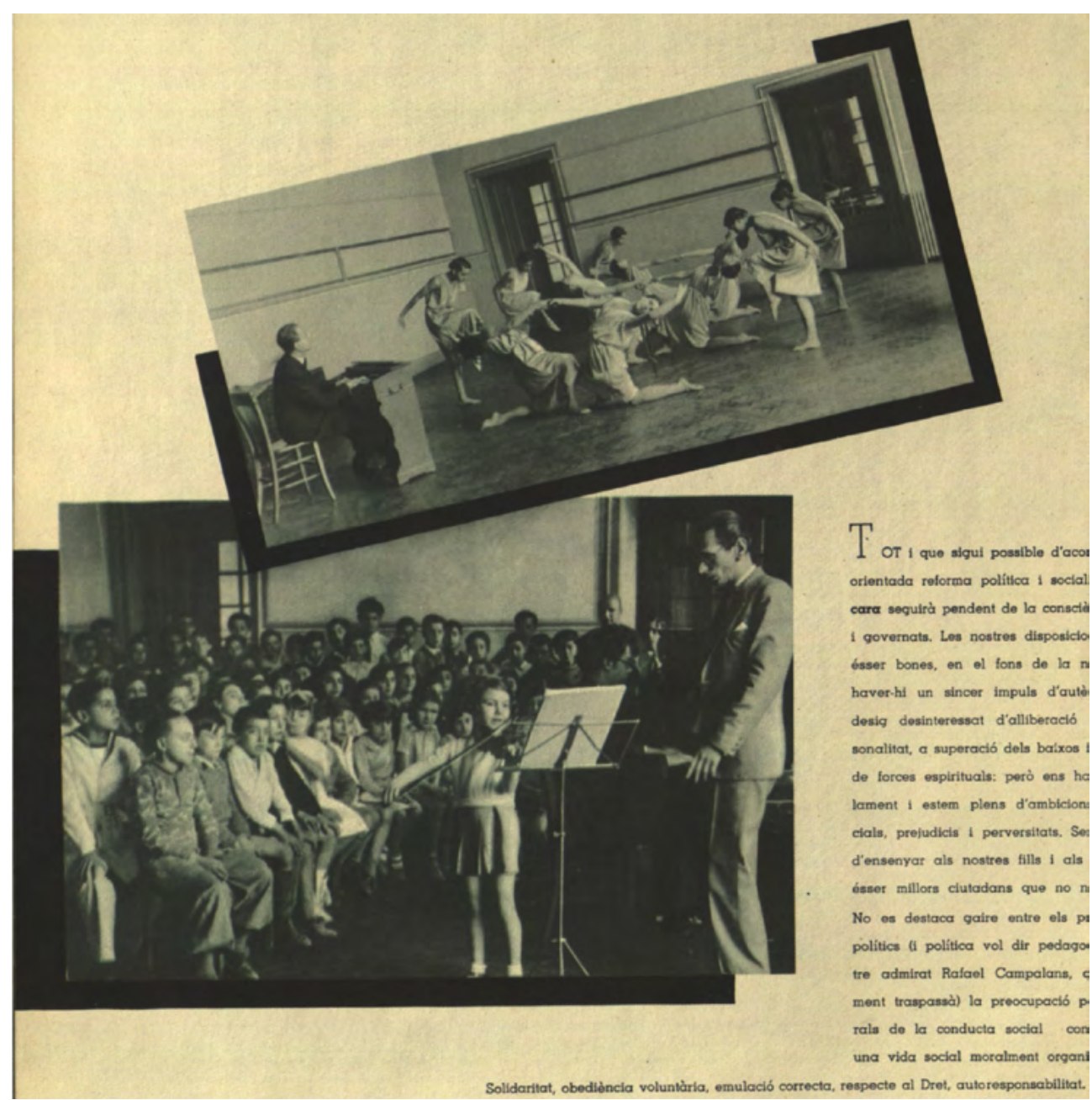

Imagen 11. Fotografías incluidas en el artículo de Marçal Pascuchi, «L'Institut Escola», Nova Iberia 3-4, marzo de 1937, s/p.

El resto de las imágenes que acompañan este artículo ilustran otras prácticas escolares que pretenden visibilizar la introducción del trabajo en la escuela. Una de las fotografías muestra un grupo de chicos realizando prácticas de navegación, mientras que en otra se ve a unas chicas en un 
laboratorio. Dos dibujos ilustran el valor que se da a la introducción del trabajo en los Institutos Escuela. Se trata de dos dibujos de Santsalvador; en el primero, un grupo de alumnos realiza trabajos de ebanistería, mientras que, en el segundo, unas alumnas elaboran utensilios de mimbre.

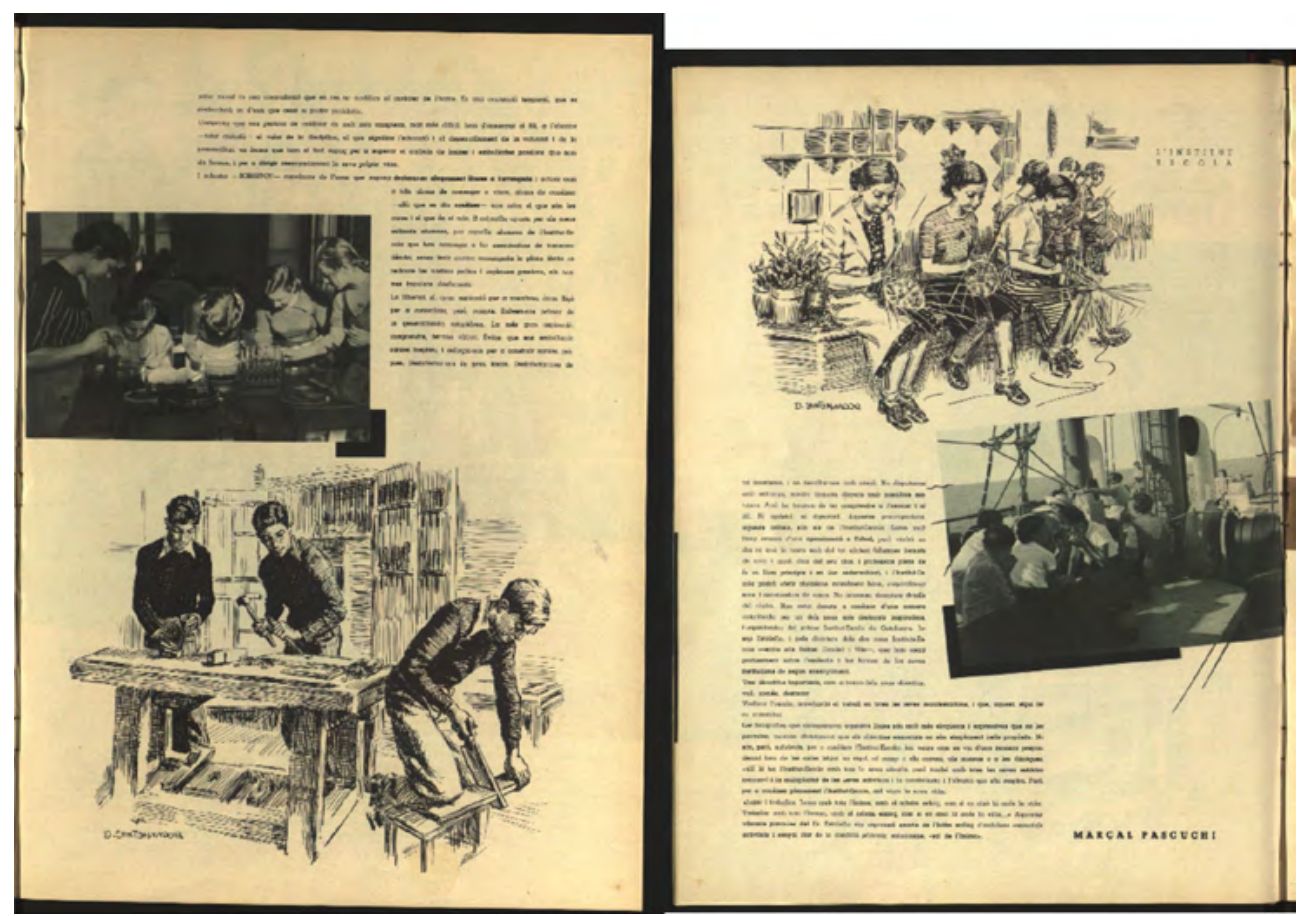

Imágenes 12-13. Dos páginas completas del artículo de Marçal Pascuchi, «L'Institut Escola», Nova Iberia 3-4, marzo de 1937, s/p.

Incorporar en la enseñanza secundaria, tradicionalmente elitista, todo tipo de trabajos productivos era uno de los objetivos de la pedagogía que el C.E.N.U. deseaba implantar en Cataluña, y con la que se esperaba obtener una sociedad más solidaria y respetuosa.

El trabajo está presente en otros artículos de este monográfico, en los que se habla de la orientación profesional en el CE.N.U. Las fotografías que ilustran estas enseñanzas profesionales, muestran instalaciones, talleres, fábricas y el interior de alguna escuela del trabajo como la de tejidos de punto de Canet de Mar. 

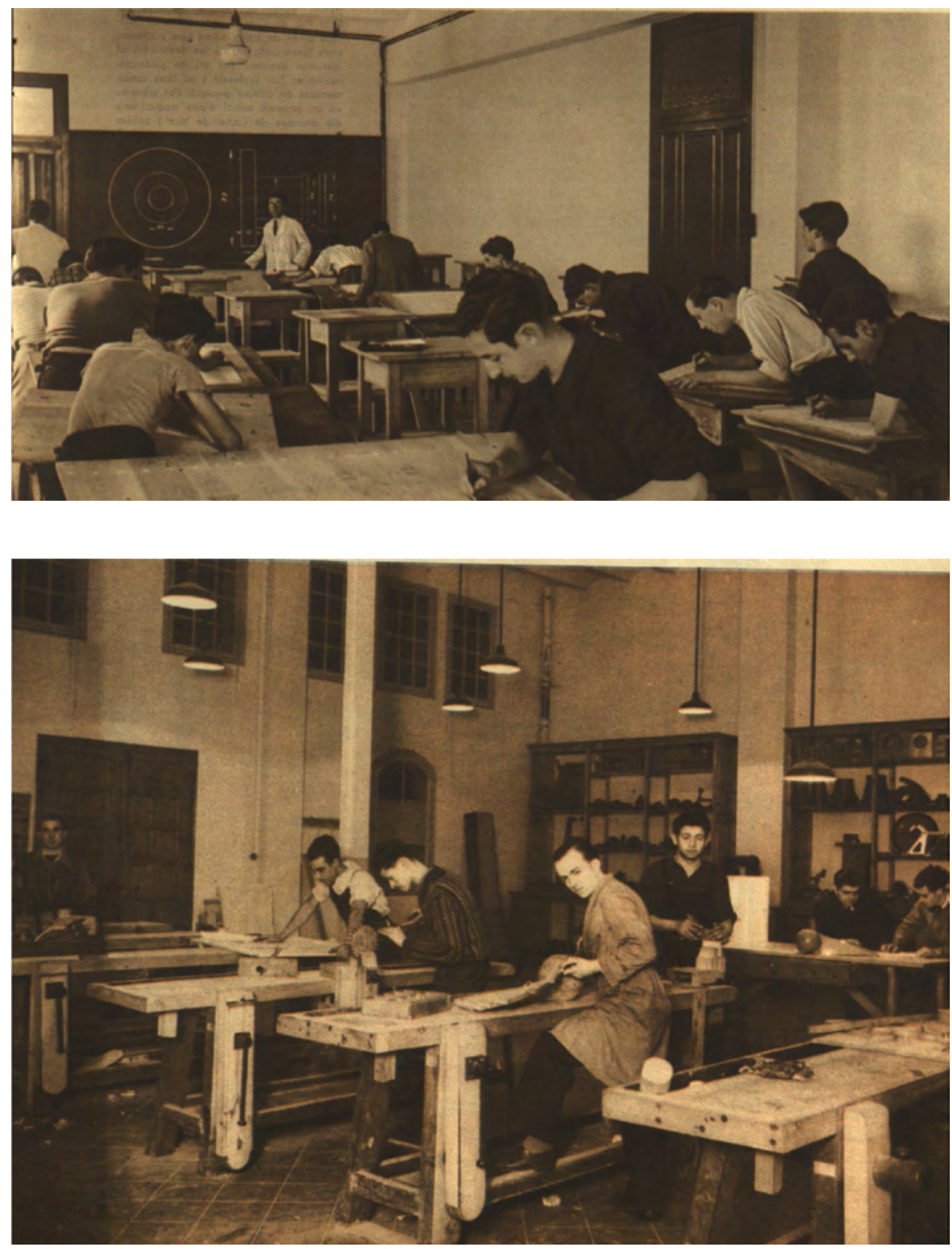

Imágenes 14-15. Fotografías incluidas en los artículos de J. Torrens-Ibern, «La escuela de géneros de punto de la Generalitat de Cataluña en Canet de Mar», y E. Ruiz Ponseti, «La enseñanza técnico industrial en Cataluña», Nova Iberia 3-4, marzo de 1937, s/p. 
Nuevamente se observan elementos iconográficos que visibilizan cómo la Cataluña revolucionaria se ocupa de la clase obrera ofreciendo no sólo una escuela que contempla el trabajo como parte esencial de la formación solidaria de todos sus ciudadanos, sino también una enseñanza profesional teórico-práctica de calidad para los jóvenes que trabajarán en un futuro en las fábricas.

\section{A MODO DE CONCLUSIÓN}

La escuela se consideraba uno de los pilares más importantes de una sociedad moderna, democrática y libre. Por ello, desde el bando republicano durante la Guerra Civil se usó el compromiso con la defensa de una escuela renovadora y para todos como argumento propagandístico a favor de su lucha armada contra el fascismo. Pensaban que una eficaz difusión de esta idea haría posible que el resto del mundo libre se diera cuenta de quienes eran los que defendían la escuela moderna frente a la barbarie, y se solidarizara con su causa. Por ello, la propaganda gráfica republicana hizo uso de la fotografía escolar en sus pósteres, carteles y revistas. La revista Nova Iberia, dentro del amplio programa desarrollado por el Comissariat, puede considerarse un buen ejemplo de cómo se usó la imagen escolar con fines propagandísticos durante la Guerra Civil en el bando republicano.

Nova Iberia intenta proyectar textual y gráficamente las principales ideas que sustentan el programa educativo de Cataluña en los primeros meses de guerra, basados en los principios racionalistas del trabajo y la solidaridad humana. Su monográfico sobre educación y cultura presenta la obra del C.E.N.U. como un proyecto de reforma educativa global, que afecta a todos los niveles de la enseñanza. No se informa de los pormenores del plan, ni se ofrecen datos concretos. Tanto el texto como las imágenes construyen un discurso sobre esta reforma educativa que sirve como apología de la revolución. Las fotografías se convierten en una representación de las ideas que fundamentan esta reforma escolar, más que en un testimonio objetivo de la práctica escolar en esos momentos. El objetivo no es hacer fotoperiodismo sino propaganda.

El análisis iconográfico e iconológico de las fotografías publicadas muestra de qué manera éstas cumplen el objetivo de difundir el idea- 
rio pedagógico y las reformas escolares revolucionarias del momento. Mediante elementos iconográficos fácilmente reconocibles por un lector nacional o extranjero, las imágenes tejen argumentos a favor de esta nueva escuela, a la vez que sutilmente justifican, legitiman y defienden la revolución armada para convertirla en realidad.

Analizadas las fotografías publicadas por Nova Iberia, concluimos que los tres grandes argumentos de la reforma educativa de la Cataluña de la Revolución que la fotografía intenta representar a través de su discurso iconográfico son la idea de modernidad pedagógica — que no es nueva, pues ya la usaron los regeneracionistas del Noucentismo durante las décadas anteriores-, la de escolarización masiva y la de introducción del trabajo en la escuela.

\section{Nota sobre las autoras}

Francisca Comas Rubí es Doctora en Ciencias de la Educación (2000), Profesora titular de Teoría e Historia de la Educación de la Universidad de las Islas Baleares y Miembro del Grupo de Estudios de Historia de la Educación de la UIB. Ha centrado su investigación en la historia de la educación en la época contemporánea, concretamente en temáticas relacionadas con la historia de la infancia y juventud, los movimientos de renovación pedagógica contemporáneos y la fotografía como fuente para la historia de la educación. Ha participado como investigadora en proyectos desarrollados en el marco de planes nacionales $\mathrm{I}+\mathrm{D}+\mathrm{I}$ sobre movimientos juveniles, y dirigido como investigadora principal tres proyectos I+D+I sobre la fotografía como fuente para la historia de la educación y uno sobre culturas y prácticas escolares en el siglo xx, este último en proceso de ejecución. Ha formado parte, como secretaria y tesorera, de la Junta directiva de la SEPHE (Sociedad para el Estudio del Patrimonio Histórico-Educativo) entre los años 2004 y 2012, y desde el año 2005 es vicepresidenta de la Societat d'Història de l'Educació dels Països de Llengua Catalana. Actualmente imparte docencia en el Grado de Pedagogía y en el Máster de Intervención Socioeducativa en Menores y Familia.

Avelina Miouel Lara es Graduada en Educación Social (2014) y máster Universitario en Intervención Socioeducativa sobre Menores y Familia 
(2015). En la actualidad realiza estudios de doctorado (Doctorado de Educación) como contratada predoctotal FPI en el marco del proyecto titulado «La fotografía publicada como representación de los cambios y las continuidades en la cultura escolar (1900-1970)», EDU2014-52498C2-2-P, financiado en el Programa Estatal de Fomento de la Investigación Científica y Técnica de Excelencia, Subprograma Estatal de Generación de Conocimiento, en el marco del Plan Estatal de Investigación Científica y Técnica y de Innovación 2013-2016 del Ministerio de Economía, Industria y Competitividad (AEI/FEDER, UE). Se halla adscrita al Departamento de Pedagogía y Didácticas Específicas. Es miembro de diversas sociedades científicas, como la Societat d'Història de l'Educació dels Països de Llengua Catalana (SHEPLLC), la Sociedad Española de Historia de la Educación (SEDHE) y la Sociedad Española para el Estudio del Patrimonio Histórico-Educativo (SEPHE). Su investigación se centra en el estudio de la fotografía publicada en la prensa de guerra republicana como fuente para la historia de la educación

\section{REFERENCIAS}

ABReu Sojo, Carlos. Los géneros periodísticos fotográficos. Barcelona: Ediciones Cims, 1997.

Alonso Erausouin, Manuel. Fotoperiodismo. Formas y códigos. Madrid: Editorial Síntesis, 1995.

Álvarez Fernández, Jesús Timoteo. Historia y modelos de la comunicación en el siglo Xx. El nuevo orden informativo. Barcelona: Ariel, 1987.

- et al. Historia de los medios de comunicación en España. Periodismo, imagen y publicidad (1900-1990). Barcelona: Ariel, 1989.

- Del viejo orden informativo, Introducción de la Historia de la Comunicación, la Información y la Propaganda de Occidente, desde sus orígenes hasta 1880. Madrid: Actas, 1991.

Batalla i Galimany, Ramon. «Jaume Miravitlles i Navarra. Intel-lectual, revolucionari $i$ home de govern. Els anys joves, 1906-1939». Tesis doctoral, Universidad Autónoma de Barcelona, 2010.

Boquera Diago, Ester. «El relevo en la propaganda oficial de la Guerra Civil española: de Jaume Miravitlles a Dionisio Ridruejo». Bulletin of Spanish Studies 89, no. 7-8 (2012): 187-199.

CAMPILlo, Maria. Escriptors catalans i compromís antifeixista (1936-1939). Barcelona: Curial Edicions Catalanes, 1994. 
Casanovas i Prat, Josep and Eulàlia Collelldemont Pujadas. «La fachada de la escuela. La imagen de la enseñanza en los films documentales de inauguración de grupos escolares durante la dictadura de Primo de Rivera». En Espacios y patrimonio histórico-educativo, editado por Paulí Dávila Balsera Árbol y Luis María Naya Garmendia, 663-678. Donostia: Erein, 2016.

Collelldemont Pujadas, Eulàlia and Josep Casanovas i Prat. «Los documentales y noticiarios como texto de apertura para pensar la educación estético-política». Historia y memoria de la Educación 5 (2017): 469-487.

Comas Rubí, Francisca and Bernat SuREdA GARCIA. «Pedagogical innovation and music education in Spain: Introducing the Dalcroze method in Catalonia». Paedagogica Historica 50, no. 3 (2014): 320-3376.

- "The photography and propaganda of the Maria Montessori method in Spain (1911-1931)». Paedagogica Historica 48, no. 4 (2012): 571-587.

Ellul, Jacques. Historie de la propagande. París: P.U.F., 1967.

Pujol, Enric. «El més petit de tots». En La revolució del bon gust, editado por Rafael Pascuet y Enric Pujol, 66-67. Figueres: Viena Edicions, 2006.

FAGEs, Pere. «Laya Films, una propaganda de cine». En La revolució del bon gust, editado por Rafael Pascuet y Enric Pujol, 112-113. Figueres: Viena Edicions, 2006.

FernÁndez SAgrera, Merche. «La fotografía i el Comissariat». En La revolució del bon gust, editado por Rafael Pascuet y Enric Pujol, 110-111. Figueres: Viena Edicions, 2006.

Figueres i Artigues, Josep M. «El Comissariat de Propaganda de la Generalitat de Catalunya: instrument propagandístic i d'agitació a la reraguarda i instrument de projecció a l'exterior». En La comunicació audiovisual en la història (V Encontre d'Historiadors de la Comunicació, editado por Arnau Company Mates, Jordi Pons Bosch and Sebastià Serra Busquets, 631-654. Palma de Mallorca: Universitat de les Illes Balears, 2003.

Fontouerni, Enriqueta and Mariona Ribalta. L'ensenyament a Catalunya durant la Guerra Civil. El CENU. Barcelona: Editorial Barcanova, 1982.

FONTSERÈ, Carles. Memòries d'un cartellista català (1931-1939). Barcelona: Editorial Pòrtic, 1995.

GIORI, Pablo. Pere Català Pic. Fotografia, publicitat, avantguarda i literatura (18891971). Barcelona: Rafael Dalmau, 2016.

Giralt-Miracle, Daniel. "Els cartells del Comissariat: cultura informativa i modernitat». En La revolució del bon gust, editado por Rafael Pascuet y Enric Pujol, 108-109. Figueres: Viena Edicions, 2006.

González Gómez, Sara, Francisca Comas Rubí and Bernat Sureda Garcia. «La renovación escolar del Ayuntamiento de Barcelona y su difusión fotográfica (1908-1936)». Revista Española de Pedagogía [aceptado para su publicación]. 
González QuintanA, Antonio. «Fuentes para el estudio de la represión franquista en el Archivo Histórico Nacional, Sección Guerra Civil». Espacio, Tiempo y Forma. Serie V, Historia Contemporánea 7 (1994): 479-508.

González, Antonio Jesús. Fotógrafo de guerra: la fotografía de guerra en España, 1859-1939. Córdoba: Diputación de Córdoba, 2015.

Guillamet i Lloveras, Jaume. «Jaume Miravitlles. Política, propaganda i periodismo». En La revolució del bon gust, editado por Rafael Pascuet y Enric Pujol, 235-244. Figueres: Viena Edicions, 2006.

Lasswell, Harold D. Porpaganda Techinique in the World War. Nueva York: Knopf, 1927.

López Mondejar, Publio. Historia de la fotografía en España. Fotografía y sociedad, desde sus orígenes hasta el siglo XXI. Barcelona: Lunwerg, 2005.

Fernández Sagrera, Merche. "Pere Català Pic: fotografía i psicología publicitaria». En La revolució del bon gust, editado por Rafael Pascuet y Enric Pujol, 46-47. Figueres: Viena Edicions, 2006.

Miquel Lara, Avelina and Francesca Comas Rubí. «La representación gráfica de la obra educativa del Segell Pro Infància en Cataluña». En Espacios y patrimonio histórico-educativos, editado por Paulí Dávila Balsera y Luis María Naya Garmendia, 813-823. Donostia: Erein, 2016.

Miravitlles i Navarra, Jaume. Gent que he conegut. Barcelona: Destino, 1979.

- Més gent que he conegut. Barcelona: Destino, 1981

Navarro Sandalinas, Ramon. L'educació a Catalunya durant la Generalitat. 19311939. Barcelona: Edicions 62, 1979.

Newhall, Beaumont. Historia de la fotografía. Barcelona: Editorial Gustavo Gili, 2001.

Oliva I DE la EsPeranza, Llúcia. «Mitjans de comunicació i memòria històrica. El Comissariat de Propaganda a través de la memòria dels que ho van viure». Treballs de Comunicació [Societat Catalana de Comunicació] 24 (2008): 3-53.

Parcerisas Colomer, Pilar. "L'ull de la fotografia moderna». En Pere Català-Pic: Fotografía y publicidad, editado por Lunwerg / Fundació «La Caixa», 9-95. Barcelona, 1998.

Pascuet, Rafael y Enric Pujol (dirs.). La revolució del bon gust, Jaume Miravitlles $i$ el Comissariat de propaganda. Barcelona: Ajuntament de Figueres, Viena Edicions, 2006.

Pizarroso Quintero, Alejandro. Historia de la propaganda: notas para un estudio de la propaganda política y de guerra. España: EUDEMA Universidad, 1990.

Planellas-Witzsch, Mark. El somriure de Catalunya. Un retrat biogràfic de Jaume Miravitlles. Barcelona: Editorial Dux, 2008.

Puig, Pere. «La revolució del bon gust. La guerra que es va guanyar». Presencia 1826 (2007): 2-11. 
Ribalta, Mariona. «Una proposta educativa global i innovadora: el C.E.N.U: (Consell d'Escola Nova Unificada)». Educació i Història 1 (1994): 125-129.

Romaguera i Ramió, Joaquim. «Els noticiaris d'actualitat en el cinema espanyol». Treballs de comunicación 7 (1996): 41-52.

Franouet i Clavet, Rosa. Historia de la radiodifusió a Catalunya (del naixement al franquisme). Barcelona, Edicions 62, 1986.

Rossell, Mercè (ed.). La Generalitat de Catalunya II. La política cultural. Barcelona: Undarius, 1977.

SAFón, Ramón. La educación en la España revolucionaria (1936-1939). Madrid: La Piqueta, 1978.

SÁnchez Vigil, Juan Miguel and María Olivera Zaldua. Fotoperiodismo y República. Madrid: Cátedra, 2014.

Solà i Gussinyer, Pere. Educació i moviment llibertari a Catalunya (1901-1939). Barcelona: Edicions 62, 1980.

Solé i Sabaté, Josep and Joan Villarroya i Font. Guerra i propaganda: fotografies del Comissariat de Propaganda de la Generalitat de Catalunya (1936-1939). Barcelona: ANC-Viena Edicions, 2006.

Sougez, Marie-Loup (coord.). Historia general de la fotografía. Madrid: Cátedra, 2006.

Sousa, Jorge Pedro. Historia crítica del fotoperiodismo occidental. Sevilla: Comunicación Social ediciones y Publicaciones, 2003.

Tiana Ferrer, Alejandro. Educación libertaria y revolución social: España 19361939. Madrid: UNED, 1987.

VEnTeo, Daniel. «Primera noticia general del Comissariat de Propaganda de la Generalitat de Catalunya (1936-1939)». En La revolució del bon gust, editado por Rafael Pascuet y Enric Pujol, 31-134. Figueres: Viena Edicions, 2006. 